\title{
Controls on reservoir quality in exhumed basins - an example from the Ordovician sandstones, Illizi basin, Algeria \\ DOI:
}

10.1016/j.marpetgeo.2016.11.011

doi:10.1016/j.marpetgeo.2016.11.011

\section{Document Version}

Accepted author manuscript

Link to publication record in Manchester Research Explorer

Citation for published version (APA):

English, K. L., English, J. M., Bonnell, L. M., Redfern, J., Lander, R. H., Hollis, C., Guirdham, C., Garnham, J., \& Yahia Cherif, R. (2017). Controls on reservoir quality in exhumed basins - an example from the Ordovician sandstones, Illizi basin, Algeria. Marine and Petroleum Geology, 80, 203-227.

https://doi.org/10.1016/j.marpetgeo.2016.11.011, https://doi.org/doi:10.1016/j.marpetgeo.2016.11.011

\section{Published in:}

Marine and Petroleum Geology

\section{Citing this paper}

Please note that where the full-text provided on Manchester Research Explorer is the Author Accepted Manuscript or Proof version this may differ from the final Published version. If citing, it is advised that you check and use the publisher's definitive version.

\section{General rights}

Copyright and moral rights for the publications made accessible in the Research Explorer are retained by the authors and/or other copyright owners and it is a condition of accessing publications that users recognise and abide by the legal requirements associated with these rights.

\section{Takedown policy}

If you believe that this document breaches copyright please refer to the University of Manchester's Takedown Procedures [http://man.ac.uk/04Y6Bo] or contact uml.scholarlycommunications@manchester.ac.uk providing relevant details, so we can investigate your claim.

\section{OPEN ACCESS}




\section{Accepted Manuscript}

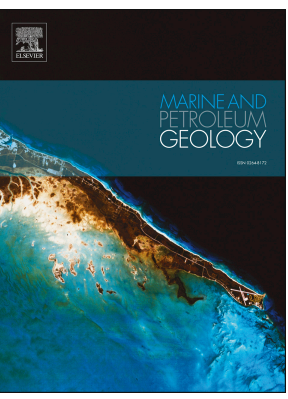

Kara L. English, Joseph M. English, Linda M. Bonnell, Robert H. Lander, Cathy Hollis Jonathan Redfern, Claire Guirdham, Jenny Garnham, Rachida Yahia Cherif

PII:

S0264-8172(16)30404-4

DOI:

10.1016/j.marpetgeo.2016.11.011

Reference: $\quad$ JMPG 2734

To appear in: $\quad$ Marine and Petroleum Geology

Received Date: 3 August 2016

Revised Date: 16 October 2016

Accepted Date: 11 November 2016

Please cite this article as: English, K.L., English, J.M., Bonnell, L.M., Lander, R.H., Hollis, C., Redfern, J., Guirdham, C., Garnham, J., Cherif, R.Y., Controls on reservoir quality in exhumed basins - An example from the Ordovician sandstone, Illizi Basin, Algeria, Marine and Petroleum Geology (2016), doi: 10.1016/j.marpetgeo.2016.11.011.

This is a PDF file of an unedited manuscript that has been accepted for publication. As a service to our customers we are providing this early version of the manuscript. The manuscript will undergo copyediting, typesetting, and review of the resulting proof before it is published in its final form. Please note that during the production process errors may be discovered which could affect the content, and all legal disclaimers that apply to the journal pertain. 


\title{
Controls on reservoir quality in exhumed basins - an example from the Ordovician sandstones, Illizi basin, Algeria
}

\author{
Kara L English \\ Petroceltic International Plc, 3 Grand Canal Plaza, Grand Canal Street Upper, Dublin 4, Ireland; E- \\ mail: kara.english@yahoo.ca

\section{Joseph M English}

Petroceltic International Plc, 3 Grand Canal Plaza, Grand Canal Street Upper, Dublin 4, Ireland; Email: dr.joe_english@yahoo.ca

\section{Linda M Bonnell}

Geocosm LLC, 10 Town Plaza \#223, Durango, Colorado, 81301, United States; E-mail:

\section{lmbonnell@geocosm.net}

\section{Robert H Lander}

Geocosm LLC, 10 Town Plaza \#223, Durango, Colorado, 81301, United States; E-mail:

roblander@geocosm.net

\section{Cathy Hollis}

School of Earth, Atmospheric and Environmental Sciences, University of Manchester, Williamson Building, Oxford Road, Manchester, M13 9PL, United Kingdom; E-mail: cathy.hollis@manchester.ac.uk

\section{Jonathan Redfern}

School of Earth, Atmospheric and Environmental Sciences, University of Manchester, Williamson Building, Oxford Road, Manchester, M13 9PL, United Kingdom; E-mail:

\section{jonathan.redfern@manchester.ac.uk}

\section{Claire Guirdham}

RPS Energy, Goldsworth House, Denton Way, Goldsworth Park, Woking, Surrey, GU21 3LG, United Kingdom; E-mail: guirdhamc@rpsgroup.com

\section{Jenny Garnham}

AGR Petroleum Services, $3^{\text {rd }}$ Floor, Union Plaza, 1 Union Wynd, Aberdeen, AB10 1SL, United Kingdom; E-mail: jenny.garnham@agr-ps.com 
1 Direction Coordination Groupe Associations - Sonatrach, Djenane El-Malik, Hydra, Algiers, Algeria;

2

3

4

5

6

7

8

9

10

11

12

13

14

15

16 Submitted to Marine and Petroleum Geology, June $7^{\text {th }} 2016$

17 Revision submitted to Marine and Petroleum Geology, August $5^{\text {th }} 2016$

18 Second revision submitted to Marine and Petroleum Geology, October $15^{\text {th }} 2016$

19 Main text word count $=9221$

20 Abstract word count $=243$

21 Number of references $=101$

22 Number of tables $=3$

23 Number of figures $=21$

24 Number of appendices $=0$

25 Data Repository $=$ No

26 Corresponding author = Kara English

E-mail: rachida.yahiacherif@Sonatrach.dz 


\section{ABSTRACT}

Petroleum exploration in many North African intracratonic basins targets Early Paleozoic sandstones as the primary reservoir objective. These sandstones are often characterized by highly variable reservoir quality $(0.0001-1,000 \mathrm{mD})$, and the ability to predict and selectively target areas of enhanced porosity and permeability is crucial to unlock the hydrocarbon potential. The objective of this study is to characterize the primary controls on reservoir quality in an Ordovician field in the Illizi Basin of Algeria through detailed core and petrographic analysis, and establish if variations in thermal history across the field have a material impact on reservoir quality. The best reservoir quality is observed in facies where primary intergranular porosity has been preserved in fine to coarse grained quartzarenites with less than $1 \%$ fibrous illite. These lithologies are most commonly found within the highenergy, tidally reworked, post-glacial facies sandstones of the uppermost Ordovician succession. Observed differences in quartz cement volume within compositionally and texturally similar samples from the southern and northern parts of the field are interpreted to reflect variations in thermal exposure due to deeper burial. This interpretation is supported by field-wide numerical modelling of sandstone diagenesis. This study indicates that subtle variations in thermal history can have a material impact on the spatial trends in reservoir permeability. Thermal history, therefore, is an important consideration in reservoir quality studies in exhumed basins where variations in present-day burial depth will be a poor guide for evaluating reservoir quality risk across a basin or play.

\section{Acknowledgements}

We thank Petroceltic International, Sonatrach, Enel, and the North African Research Group (University of Manchester) for sponsoring this study, and Sonatrach for granting permission for publication. We gratefully acknowledge the generous donations of Genesis and Touchstone software for this research. This research also benefitted from contributions and support from Kevin Isaac, Jonathan Hunter, John Naismith, Ciaran Nolan, Dermot Corcoran, Brian O’Cathain, Geoff Probert, Andy Lever, Balz Kamber, Neil Kearney, Rick Tobin, Djamila Daoudi, Toyoki Nishibayashi and three anonymous reviewers. 


\subsection{Introduction}

Early Paleozoic clastics are the main reservoir target in many North African intracratonic basins, but they can be challenging to develop due to the risk of poor reservoir quality. These ancient systems have had ample time for reservoir degradation through compaction and cementation, and predicting the 'sweet spots' with enhanced productivity is often key to their success. Upper Ordovician (Ashgillian) glacial to marine deposits are an example of such a system and have been described all across the northern margin of Gondwana from Mauritania (Ghienne and Deynoux, 1998) and Morocco (Destombes et al., 1985; Le Heron, 2007; Le Heron et al., 2007), through Algeria (Beuf et al., 1971; Ghienne et al., 2007a), Niger (Denis et al., 2007) and Libya (Le Heron et al., 2004; Moreau et al., 2005; Le Heron et al., 2006; Ghienne et al., 2007b; Le Heron et al., 2010; Moreau, 2011; Ghienne et al., 2013), and over to Jordan (Powell et al., 1994; Turner et al., 2005) and Saudi Arabia (Vaslet, 1990). Within the Illizi Basin of Algeria (Fig. 1), Ordovician sandstones are important reservoirs containing extensive hydrocarbon accumulations (Boote et al., 1998; Le Heron et al., 2009) and significant fields include Tin Fouyé Tabankort (Askri et al., 1995; Le Maux et al., 2006), Ohanet (Philippe et al., 2003), and In Amenas (Dixon et al., 2008b; Roussé et al., 2009; Hirst, 2012).

The reservoir quality of the Upper Ordovician Unit IV sandstone (Fig. 2) is highly variable in the Illizi Basin (e.g. Hirst et al., 2002; Hirst, 2012; Wells et al., 2015; Hirst, 2016). The best reservoir quality found in the In Amenas area is contained in the post-glacial shallow marine sandstones (Unit IV-3 equivalent), as well as in proximal and medial glaciomarine fan sandstones (Unit IV-1 equivalent) (Lang et al., 2012). Within the synglacial succession (Units IV-1 and IV-2), the best reservoir properties have been interpreted to correspond to coarse-grained jet-efflux deposits and laterally extensive high-density turbidite flows with low mud content, whilst the poorest reservoir quality is found in muddy debris flow deposits (Hirst et al., 2002). At the Tin Fouyé Tabankort field, the best reservoir quality occurs in the post-glacial Unit IV-3 sandstones (Askri et al., 1995; Le Maux et al., 2006). Previous Algerian studies determined the main controls on Ordovician reservoir quality to be the degree of mechanical and chemical compaction, fibrous illite and quartz cementation, grain size (Kaced, 2003; Ahnet Basin), clay coatings (Tournier et al., 2010; Sbaa Basin), silica source, and possibly the presence of bitumen or oil to slow the rate of quartz cementation (Haddad et al., 2005; Wells et al., 2015; Illizi Basin). However, the 
1

impact of spatial variation in thermal history on Ordovician reservoir quality was not directly addressed by these previous studies.

The focus of this study is on an Upper Ordovician reservoir located in a gascondensate field in the southern Illizi Basin (Fig. 1). Burial history reconstructions indicate that maximum burial most likely occurred during the early Eocene, prior to Eocene-Miocene exhumation and northward tilting of the Illizi Basin (English et al., 2016b). Based on 1dimensional (1D) thermal history modelling, maximum burial depths and temperatures for the top Ordovician are estimated at $2.95 \mathrm{~km}$ and $140^{\circ} \mathrm{C}$ in the northern part of the field and $3.37 \mathrm{~km}$ and $156^{\circ} \mathrm{C}$ in the southern part of the field, although present-day burial depths in these areas are now similar (English et al., 2016c). The objectives of this study are to:

1) characterize the reservoir through detailed core and petrographic analysis, and establish the primary controls on reservoir quality,

2) utilize the rock properties and thermal history reconstructions for the study area to constrain the temporal evolution of porosity and permeability via diagenetic modelling, and

3) establish if the observed variations in thermal history across the field have a material impact on reservoir quality and discuss the broader implications for other exhumed basins.

\subsection{Geological Background}

\subsection{Illizi Basin and Study Area}

The Berkine and Illizi basins are situated on the North African Platform and contain more than 6000 m of Paleozoic-Mesozoic strata (Echikh, 1998; Dixon et al., 2010; Galeazzi et al., 2010). The North African Platform was the site of widespread clastic-dominated deposition on the northern margin of Gondwana throughout the Paleozoic (Beuf et al., 1971; Stampfli and Borel, 2002; Guiraud et al., 2005; Konaté et al., 2006; Dixon et al., 2010). During the late Carboniferous, the platform was segmented into separate basins by extensive uplift and erosion along north-south trending arches associated with the Hercynian (Variscan) Orogeny (Aliev et al., 1971; Beuf et al., 1971; Fabre, 1976; Boudjema, 1987; van de Weerd and Ware, 1994; Guiraud et al., 2005). Renewed deposition during the Mesozoic and Cenozoic occurred following the break-up of Gondwana and the opening of the Tethyan 
seaway to the north (Boote et al., 1998; Galeazzi et al., 2010). Sedimentation in the Berkine and Illizi basins continued until Mid-Late Eocene "Pyrenean" inversion, which caused growth of the Atlas range to the north and reactivation of some pre-existing fault systems further south (Echikh, 1998). Intraplate uplift and magmatism initiated in the Hoggar Massif during the Mid-Late Eocene (e.g. Liégeois et al., 2005; Rougier et al., 2013) leading to largescale exhumation of the flanking Illizi Basin to the north of the Hoggar (English et al., 2016b).

The study area is a multi-TCF (trillion cubic feet) gas-condensate field in the southern Illizi Basin (Fig. 1), which is characterized by a large $(80 \mathrm{~km}$ by $50 \mathrm{~km})$ low-relief four-way dip closure containing a hydrocarbon column in excess of $100 \mathrm{~m}$. The reservoir sequence comprises Upper Ordovician glacio-marine to post-glacial marine sandstones (Fig. 2). This sequence is capped by thick (250-300 m) lower Silurian graptolitic shales (Fig. 2), which act as a regionally extensive seal. The shales were deposited during eustatic sea-level rise associated with the final deglaciation (Lüning et al., 2000; Legrand, 2003; Grabowski, 2005; Le Heron and Craig, 2008; Moreau, 2011; Galeazzi et al., 2010). The basal part of these mudstones often contains a radioactive organic-rich interval that serves as an important Paleozoic source rock across North Africa and the Middle East (Boote et al., 1998; Lüning et al., 2000). Maturity of the Silurian source rock ranges between $0.9-1.3 \% \mathrm{R}_{\mathrm{o}}$ across the field area with an increase in maturity observed towards the south and off the flanks due to increasing depth of maximum burial (English et al., 2016c).

The present-day reservoir temperature in the study area is $\sim 95-100^{\circ} \mathrm{C}$, but burial and thermal history reconstructions using thermal maturity, apatite fission-track, and sonic velocity data indicate that elevated temperatures and deeper burial occurred in the past (Fig. 3; English et al., 2016c). Maximum burial most likely occurred during the early Eocene with estimated maximum burial depths and temperatures for the top Ordovician ranging from $~ 3.0$ $\mathrm{km}$ and $140^{\circ} \mathrm{C}$ in the north (Well A) to $\sim 3.4 \mathrm{~km}$ and $156^{\circ} \mathrm{C}$ in the south (Well G) of the field (English et al., 2016c). Oil generation from the overlying Silurian source rock began during the Carboniferous period but ceased during inversion associated with the Hercynian orogeny. Following reburial during the Mesozoic and early Cenozoic, minor oil and gas generation occurred before final cessation of hydrocarbon generation during Cenozoic exhumation (English et al., 2016c). The estimated magnitudes of subsequent Cenozoic exhumation are 
variable across the field due to the northward tilting of the basin, and range from $1.0 \mathrm{~km}$ in the north (Well A) to $1.4 \mathrm{~km}$ in the south (Well G).

\subsection{Ordovician Stratigraphy}

The Ordovician sequence has been studied extensively in outcrop along the southern margin of the Illizi Basin in the Tassili N'Ajjer region (Bennacef et al., 1971; Beuf et al., 1971; Hirst et al., 2002; Eschard et al., 2005; Girard et al., 2012; Deschamps et al., 2013), and also in the subsurface (Hirst et al., 2002; Galeazzi et al., 2010; Roussé et al., 2009; Hirst, 2012; Lang et al., 2012; Hirst, 2016). The Upper Cambrian-Lower Ordovician sequence (Unit II in subsurface; Ajjers Formation in outcrop; Fig. 2) is characterized by amalgamated sandy fluvial deposits resting upon eroded Pan-African basement. Subsequent shallow marine deposition of the Unit III records a period of transgression during the Ordovician Tremadoc to Llanvirn (Fig. 2; Bennacef et al., 1971, Beuf et al., 1971; Eschard et al., 2005).

Eustatic sea-level fall and glacial scouring was associated with the short-lived Ashgillian glaciation (Brenchley et al., 1994; Armstrong and Coe, 1997; Sutcliffe et al., 2000; Moreau et al., 2005; Le Heron and Craig, 2008), when North Africa was situated near the South Pole (e.g., Hambrey, 1985; Stampfli and Borel, 2002). The Ashgillian (or locally termed Taconic) Unconformity provides evidence of this period of glacial incision. Deep erosion of the underlying 'pre-glacial' strata by subglacial tunnel valleys or glacial valleys led to laterally constrained deposition of the syn-glacial lower Tamadjert Formation or Unit IV, although later deposits may blanket both the valley-fills and the interfluves (Fig. 4). The glaciogenic deposits predominantly comprise diamictites and glaciomarine fan deposits, with the diamictites representing deposits of the glacial maximum, and retrogradational (iceproximal to ice-distal) glaciomarine fan deposition occurring during glacial retreat (Lang et al., 2012). Within the Illizi Basin, the depositional record of the Unit IV is dominated by glaciomarine ice-contact fans situated in front of a retreating ice sheet (Fig. 5A). Proximal coarse-grained facies in the Illizi Basin to the south transition to fine-grained distal facies in the Berkine Basin to north (Galeazzi et al., 2010). These glaciogenic deposits are characterized by complex lateral and vertical facies changes as a result of multiple phases of ice-sheet advance and retreat, glaciotectonic deformation and syn-glacial tectonic activity (Hirst et al., 2002; Roussé et al., 2009; Lang et al., 2012). 
In the study area, the lower syn-glacial Unit IV stratigraphic sequence is subdivided into the Unit IV-1 and Unit IV-2 (Fig. 2). The Unit IV-1 comprises sand-rich proximal highenergy deposits and the overlying Unit IV-2 comprises distal low-energy turbidites and intervening hemipelagic deposits. The disappearance of ice-rafted debris within the Unit IV-2 represents the termination of glaciomarine conditions. A regionally extensive post-glacial sandstone unit known as the Dalle de M'Kratta (Galeazzi et al., 2010), or the Unit IV-3 in the subsurface of the Illizi Basin, blankets the glacial deposits (Figs. 2 and 4). This important post-glacial shallow marine unit typically consists of fine to coarse grained, moderately-well sorted, cross-bedded sandstones, containing ooids and skolithos, indicating a marine influence (Hirst et al., 2002). These sandstones contain the best reservoir quality in the study area and are important to characterize for the development of the field.

The Unit IV-3 is typically $<40 \mathrm{~m}$ thick (Galeazzi et al., 2010), averaging $20 \mathrm{~m}$ thickness at the Tin Fouyé Tabankort field (Fig. 1; Askri et al., 1995; Le Maux et al., 2006), but is described as laterally discontinuous over $100 \mathrm{~s}$ to $1,000 \mathrm{~s}$ of metres both at the Tiguentourine field (In Amenas area) and at outcrop (Hirst et al., 2002; Hirst, 2016). At outcrop in the Gara Nessaret area of the Tassili N'Ajjer (Fig. 4), these deposits form elongate sand banks (Beuf et al., 1971; Fig. 5), and are interpreted to have been deposited in a tidallyinfluenced shallow-marine environment (Dixon et al., 2008a; Hirst, 2016). These tidal sand wave deposits form long (at least $4 \mathrm{~km}$ ), N-S oriented curvi-linear ridges with heights up to 4 $\mathrm{m}$, widths from $90 \mathrm{~m}$ to $160 \mathrm{~m}$, and typical crest-to-crest distances of $\sim 150 \mathrm{~m}$ (Fig. 5; Dixon et al., 2008a). Although the coarser sandstone deposits thin from the crest of the ridges into the intervening troughs, they are still continuous across the troughs so that the entire sand body comprises an extensive sheet (Hirst, 2016).

Overall, the Unit IV-3 records transgressive early post-glacial deposition that was influenced by remnant glacial topography, which may have been subjected to post-glacial isostatic rebound. At the Tiguentourine field, Roussé et al. (2009) observe mud-prone deposits thickening into underfilled post-glacial depressions, while co-eval remnant palaeohighs are characterized by erosion and reworking, leading to shallow marine sand-prone deposits in the more elevated areas. A similar model has been proposed for the latest Ordovician deglaciation sequence in the Murzuq Basin in Libya (Moreau, 2011). The emergence of new topographic highs during isostatic rebound may have resulted in the cannibalising and reworking of pre-existing syn-glacial sediments during the overall post- 
glacial marine transgression. A major post-glacial paleo-topographic high within the Illizi Basin has been previously interpreted in the study area (Isarene high; English et al., 2016c). It is possible that this paleo-high was characterized by reworking during latest Ordovician time leading to the deposition of more extensive tidally-reworked Unit IV-3 sands in this area.

\subsection{Methodology}

\subsection{Core and Petrographic Analysis}

Porosity and permeability analysis was conducted on 417 core samples from eight different wells in the study area. The analysis was carried out using a $\mathrm{CMS}^{\mathrm{TM}_{3}} 300$ (Core Measurement System, Model 300 Stage 4.0) automated permeameter-porosimeter, which uses helium for measurements under normal conditions, but switches to nitrogen in low permeability samples to provide accurate measurements down to $0.00005 \mathrm{mD}$. All baseline permeability values presented here use a confining stress of 800 psia and are Klinkenbergcorrected to account for the difference in gas behaviour at low pressures versus high pressures. The permeability of a rock can also be very sensitive to the magnitude of confining stress, especially for lower permeability rocks. In order to evaluate the impact of higher confining stress, the porosity and permeability of 69 samples were measured as the confining stress was increased from the baseline of 800 psia up through 1900, 3300, 4500 and 6000 psia.

Laboratory capillary pressure measurements from reservoir rocks were used to characterize the pore geometry and pore throat size distribution, and to predict vertical hydrocarbon saturation profiles above a free water level (FWL) for a given rock type (Vavra et al., 1992; Hartmann and Beaumont, 1999). Mercury injection capillary pressure (MICP) tests were conducted on 29 Ordovician sandstone samples, where mercury (the non-wetting phase) saturation in the core plug increases as the injection pressure is incrementally increased. Pore throat size distributions were generated for each sample analyzed, and the pore throats (ports) were classified as nanoports, microports, mesoports, macroports and megaports according to the scheme of Hartmann and Beaumont (1999).

Seventy (70) thin-sections from sandstone core plugs selected from the core analysis sample set were petrographically analysed. The original coring program focussed on the Unit IV-3 and hence, all the samples are from the uppermost $50 \mathrm{~m}$ of the Ordovician sequence 
with 49, 11 and 10 samples from the Units IV-3, IV-2 and IV-1 respectively. Thin-sections were set in blue resin to help identify porosity, and then stained for potassium feldspar (using sodium cobalt nitrite) and carbonate (using Alizarin Red-S and potassium ferricyanide). Each thin-section was visually described by the lead author and quantification of mineralogy, paragenesis and porosity was obtained by counting 300 points with a Leica microscope. Each thin-section was photographed (at magnifications of $5 \mathrm{x}, 10 \mathrm{x}, 20 \mathrm{x}$ and $50 \mathrm{x}$ ) to take digital measurements of grain size, grain coat coverage, and intergranular pore sizes using JMicroVision $^{\mathrm{TM}}$ image analysis software (Roduit, 2006; version 1.2.7). The major axes of all grains were measured in each thin-section, and area-weighted to calculate the mean grain size and Trask sorting (sqrt P75/P25). Environmental scanning electron microscope (ESEM) imagery, x-ray diffraction (XRD) data, and limited cathdoluminescence data were used to support petrographic analysis. Fluid inclusion data collected from seven wells yielded homogenization temperatures, salinity and/or API gravity measurements, and were used to constrain the time-temperature history of quartz and barite cements (English et al., 2016a; English et al., 2016c).

\subsection{Numerical Modelling of Sandstone Diagenesis}

Numerical forward models are now available to simulate the evolution of sandstone porosity and permeability over geologic time by modelling compaction, quartz cementation, and other diagenetic processes as a function of thermal and effective stress history (e.g. Pittman and Larese, 1991; Walderhaug, 1994, 1996, 2000; Lander et al., 1997, 2008, 2009; Bjørkum et al., 1998; Bonnell et al., 1998, 1999, 2000; Lander and Walderhaug, 1999; Perez et al., 1999; Bloch et al., 2002; Helset et al., 2002; Paxton et al., 2002; Morantes, 2003; Taylor et al., 2004, 2010, 2015; Makowitz et al., 2006, 2010; Lewis et al., 2007; Perez and Boles, 2006; Ajdukiewicz and Lander, 2010; Lander and Bonnell, 2010; Tobin et al., 2010; Hyodo et al., 2014; Tobin and Schwarzer, 2014; Lander and Laubach, 2015; Busch et al., in press). In this study, diagenetic modelling of 20 samples from the high-permeability facies was carried out using Touchstone ${ }^{\mathrm{TM}}$ software (version 7.4.2). These samples were selected on the basis of being compositionally and texturally similar in terms of their primary depositional characteristics, and hence, they provide a solid suite of data to model the impact of variable thermal history on reservoir quality across the study area. Model parameters were 
optimized to match present-day petrographic and reservoir properties (this study) using published burial and thermal history models for the study area wells (English et al., 2016c).

Touchstone simulates mechanical compaction through time by taking into account the original grain-size distribution and intergranular volume (IGV), the mechanical properties of the framework grains, the strengthening effects of the cement phases, and the effective stress history. In selected samples with observed chemical compaction, an additional IGV loss was applied to match the measured IGV. The onset of the chemical compaction is assumed to occur at $80^{\circ} \mathrm{C}$. Quartz cementation is modelled using an Arrhenius expression that results in an exponential rate increase with temperature (Walderhaug, 2000; Lander et al., 2008). The amount of quartz cement is a function of thermal exposure (i.e., temperature and time), the nucleation surface area available for quartz cementation, and the grain size. The nucleation surface area available for quartz cementation is governed by the sandstone composition and texture, but can also decrease in the presence of grain coatings (Heald and Larese, 1974) or during compaction (Lander and Walderhaug, 1999; Lander et al., 2008). Finally, net quartz cement rates are affected by grain size because smaller grains become dominated by slowgrowing euhedral faces more rapidly compared to larger equivalents (Lander et al., 2008).

Quartz cementation is not assumed to be limited by silica supply, and the activation energy for quartz precipitation is optimized during the modelling to achieve a good match between the measured and calculated quartz cement abundances for each sample. The other (non-quartz) authigenic phases are relatively minor in the high-permeability facies, and are modelled using paragenesis rules and abundances based on the petrographic observations. The reduction in intergranular porosity over time is modelled as a function of compaction and cementation, and the permeability is modelled using an extension of the work by Panda and Lake (1994, 1995). Various permeability model parameters are optimized to match core measurements such as specific surface areas for pore-filling cements and detrital clay, tortuosity differences between intergranular and secondary pores, and microporosity effectiveness. Secondary porosity and microporosity, however, are relatively minor in the high-permeability samples that were the focus of this modelling work.

The input parameters for the model were optimized using a genetic algorithm optimization engine and a fitness function that determined the magnitude of the error between the simulation results and four categories of measured data: (1) measured intergranular pore volume (IGV), a proxy for the sandstone compaction state, (2) quartz cement volume, (3) 
core porosity, and (4) core permeability. Each category was optimized until $100 \%$ of measured data simultaneously fell within tolerance limits of \pm 4 vol. $\%$ for IGV, quartz cement volume and porosity, and within an order of magnitude for permeability.

After completing the parameter optimization procedure, the next step in the modelling process consists of describing the variations in compositional and textural characteristics for the high-permeability dataset to obtain a more realistic depiction of the variability in reservoir quality. This involved selecting probability distribution types to fit data from the actual samples. We also used statistical copulas that describe any dominant co-variations among these characteristics. Using this information, 5000 realizations were generated to describe the compositional and textural variability of the sandstone type of interest. These realizations, in turn, serve as input for the forward models and predicted reservoir quality distributions for burial histories away from well control. We conducted such simulations for the reservoir intervals at the well locations to ensure that the predicted distributions are consistent with available data.

We next used $\mathrm{T}>\mathrm{Map}^{\mathrm{TM}}$ software (version 3.2) to predict the reservoir quality distribution for the sandstone type using a burial history reconstruction for the reservoir interval over the study region. T>Map uses the same numeric engine as Touchstone but conducts simulations on volumes or map surfaces. To derive burial histories for the reservoir over the map region, we first created a total of six 1D burial history models (including Wells A and G) with Genesis software (Zetaware) using preserved stratigraphy, well data and parameters from English et al. (2016c). These 1D models were then integrated with available isopach maps and a maximum burial map (English et al., 2016c) to generate a suite of burial depth, thermal history, and effective stress maps across the study area for 15 different geologic time-steps between time of deposition and present-day.

\subsection{Core Analysis Results}

\subsection{Porosity and Permeability}

The Ordovician sandstone reservoir quality in the study area is variable, and a compilation of the core porosity-permeability data from the field shows two main trends (Fig. 6A; Table 1). Higher permeability and lower permeability samples are referred to herein as Group A and Group B respectively (Fig. 6B) with a permeability cut-off of $\sim 0.1 \mathrm{mD}$. It is 
worth noting that the core database for the field provides good coverage of the Unit IV-3 and Unit IV-2, but the deeper Unit IV-1 is relatively undersampled because the economic focus is typically on the Unit IV-3 in this part of the basin.

The high permeability samples (Group A) are predominantly from the post-glacial marine, fine-coarse grained, poorly to well sorted sandstones within the Unit IV-3, but can also occur locally within medium-grained, moderately sorted sandstones within the synglacial Unit IV-1 (Fig. 6A). Based on the limited Unit IV-1 dataset, it is possible that the high-permeability facies in this unit has a different porosity-permeability trend to the better reservoir quality in the Unit IV-3 (Fig. 6A). Lower permeability Group B samples are found in all stratigraphic units (Units IV-1, IV-2 and IV-3; Fig. 6A). Within the lower permeability samples, there appears to be slightly improved permeability in the Unit IV-1 sandstones versus the Unit IV-2 (Fig. 6; Table 1). This improvement may reflect a vertical stratigraphic sequence from medial fan high-density turbidites in the Unit IV-1 upwards into more distal facies and finer-grained low-density turbidites in the Unit IV-2.

\subsection{Impact of Confining Stress on Porosity}

Porosity and permeability were observed to be most significantly reduced during the initial increase in confining stress (800 to 1900 psia), with relatively less reduction thereafter (e.g. 1900 to 3300, 4500, and 6000 psia, Fig. 7). The effect of increasing confining stress on porosity in Group A sandstones is relatively minor, with less than $10 \%$ fractional reduction in pore volume, even at 6,000 psia. Most of the Group B sandstones with porosity $>5 \%$ are characterized by fractional pore volume reduction of less than $10 \%$ (from 800 to 6,000 psia). However, Group B samples with porosity $<5 \%$ appear to be the most variable and most stress sensitive, with fractional pore volume reduction typically ranging from 5\% up to 50\% (from 800 to $6,000 \mathrm{psia}$ ). In general, the absolute magnitude of pore volume reduction averages $0.7 \%$, but this is proportionately more significant within the lower porosity samples.

\subsection{Impact of Confining Stress on Permeability}

Confining stress has a more significant effect on permeability compared to porosity as the increased compression restricts the pore throats that control fluid flow, particularly in lower permeability rocks. As with porosity, increasing confining stress in the higher 
1 permeability Group A sandstones results in relatively minor (less than 10\%) fractional

2 reduction in permeability between 800 and 6,000 psia confining stress (Fig. 7). Stress sensitivity of the lower permeability Group B is much more significant where samples with permeability $>0.03 \mathrm{mD}$ are characterized by a fractional reduction of permeability ranging from $40 \%$ to $80 \%$ between 800 and 6,000 psia. In contrast, Group B samples with permeability $<0.03 \mathrm{mD}$ are characterized by a higher fractional reduction of permeability ranging from $60 \%$ to $99 \%$ with the absolute reduction in permeability frequently being between 1 and 2 orders of magnitude.

\subsection{Capillary Pressure Data and Pore Throat Size Distributions}

While there is only a partial overlap between the mercury injection capillary pressure (MICP) and core analysis sample sets, a similar classification of Group A and Group B can still be applied to the MICP dataset on the basis of permeability. The permeability values cited here for the MICP samples are permeability to air measurements taken at a confining stress of 400 psia, and a permeability cut-off of $0.5 \mathrm{mD}$ was used to distinguish Group A from Group B. It should be noted that no direct confining stress is applied during the MICP tests, and that additional confining stresses typical of subsurface conditions are likely to result in lower permeabilities and higher capillary pressures (Shanley et al., 2004).

The higher permeability Group A sandstones are predominantly characterized by macroports and megaports (Fig. 8A; Table 1) with the highest permeability being associated with the largest modal pore throat radii (Fig. 8B). In contrast, and as expected, the lower permeability Group B sandstones are predominantly characterized by smaller microports, and even nanoports in the case of the lowest permeability samples (Fig. 8A). Overall, there is a strong positive correlation between modal pore throat radius and permeability (Fig. 8B) with the outliers being associated with bimodal or broad pore throat size distributions (Fig. 8A). Within the Group B samples, even though the Unit IV-3 and Unit IV-1 samples have porosities less than $6 \%$, the data illustrate that they tend to have larger modal pore throat radii than the Unit IV-2 samples (Fig. 8B; Table 1). The two Unit IV-2 samples with comparable modal pore throat radii have the highest porosity $(>10 \%)$ of the Unit IV-2 subset.

\subsection{Implications for Vertical Saturation Profiles}


In the case of a primary hydrocarbon charge of a water-wet reservoir, the capillary pressure determines the ease of which the non-wetting phase (oil or gas) can displace the wetting phase (brine). In order to apply the MICP data to the subsurface, the laboratory air/mercury system needs to be converted to the subsurface brine/hydrocarbon system of the reservoir (e.g. Vavra et al., 1992). Following this conversion, and using assumed brine and hydrocarbon densities, it is possible to construct theoretical vertical saturation profiles (above free water level) for both oil and gas (Fig. 9). One caveat of this approach is that it assumes hydrocarbon saturations are driven by drainage (i.e. the displacement of wetting phase brine by non-wetting phase hydrocarbons) and that the present-day capillary characteristics of the reservoir as measured in the laboratory are representative of those at the time of hydrocarbon charge (Shanley et al., 2004; Shanley and Cluff, 2015), in this study, in the Carboniferous and onwards (English et al., 2016c).

The higher permeability Group A sandstones are characterized by low capillary entry pressures $(<15$ psia; Table 1) and the height above free water level (HAFWL) saturation curves display a sharp transition zone from the water leg into a hydrocarbon column with water saturations less than $10 \%$ (Fig. 9B). Group A samples with permeability less than 10 $\mathrm{mD}$ also show a relatively abrupt transition zone, but have slightly higher irreducible water saturations - although still less than 10\% (Fig. 9B). In contrast, the lower permeability Group B sandstones are characterized by capillary entry pressures in excess of 100 psia (Table 1), and the capillary entry pressures tend to be highest for the lowest permeability samples (Fig. 9B). As noted above with the discussion of pore throat radii, Group B samples from the Unit IV-3 and Unit IV-1 have slightly better reservoir quality and hence lower capillary entry pressures than their Unit IV-2 equivalents (Fig. 9A).

From a petroleum engineering perspective, these HAFWL curves indicate that the Group B sandstones will tend to be associated with greater vertical separation between the FWL and the hydrocarbon-water contact (HCWC), and longer, more gradual transition zones (Fig. 9). This effect will be even more pronounced for oil versus gas columns, and also for the lower porosity and permeability samples of the Unit IV-2 (Fig. 9A). A key implication is that petroleum traps of analogous Ordovician reservoirs will require vertical closures in excess of $80 \mathrm{~m}$ and $200 \mathrm{~m}$ for gas and oil respectively in order to attain water saturations below $40 \%$ within Group B quality sandstones. An additional implication is that the highly variable capillary characteristics of the Ordovician sandstones are likely to give rise to 
1

2

3

4

5

6

7

8

9

complex vertical saturation profiles and variable HCWCs due to vertical and lateral variations in reservoir quality.

\subsection{Petrographic Results}

In this study, 70 core plugs were analysed petrographically to evaluate the primary controls on porosity and permeability in the Upper Ordovician reservoir (Fig. 6B). The Group A samples have a core porosity range of $4.7-11.4 \%$ (average $7.0 \%$ ) and a permeability range of 0.1-377.9 mD, and Group B samples have a core porosity range of $1.3-11.8 \%$ (average $4.8 \%$ ) and a permeability range of $0.0005-0.0496 \mathrm{mD}$. See Table 2 for further details on the petrographic subset.

\subsection{Depositional Texture and Compaction}

\subsubsection{Group A}

The high permeability Group A samples (Fig. 6B; 25 samples) comprise fine to coarse grained, poorly to moderately-well sorted sandstones (Figs. 10A and 10B; Table 2). In this subset, grain-grain dissolution is common where boundaries are often straight to concaveconvex, or less commonly sutured. The intergranular pore volume (IGV) is defined as the sum of the pore space, cement and matrix, and is primarily a function of depositional IGV, mechanical strength, and maximum effective stress (Lander and Walderhaug, 1999). The IGV estimates derived from petrography range between 15 and 28\% (average 24\%; Table 2). The upper bound is consistent with rigid grain-rich sandstones lacking grain-to-grain dissolution (e.g. Paxton et al., 2002), whereas the lower bound reflects increased grain to grain dissolution and microstylolitic textures (3 samples).

\subsubsection{Group B}

The lower permeability Group B samples (Fig. 6B; 45 samples) are most commonly moderate to moderately well sorted, and very fine to fine grained sandstones (Figs. 10A and 10B) and are typically finer grained than the Group A samples (Table 2; Fig. 11). IGV values range between 16 and 42\% (average 26\%; Table 2) and samples with the highest IGVs contain higher contents of cements. Grain boundaries are often straight, concave-convex or 
severely sutured, and grain-to-grain chemical compaction is observed in many samples in the dataset. Stylolitic textures along zones of condensed primary clay are more common (20 samples) than in Group A. Textural evidence of enhanced chemical compaction coincides with lower IGV values in the sample set, and indicates contact dissolution is significant in some of these samples.

\subsubsection{Stratigraphic Controls on Mean Grain Size}

Ordovician sandstones of the post-glacial Unit IV-3 and syn-glacial Unit IV-1 are typically fine to medium grained, whereas the syn-glacial Unit IV-2 sandstones are very fine to fine grained (Fig. 11). Stratigraphic grain size variation within the syn-glacial succession may reflect a vertical transition from a more proximal (Unit IV-1) to a more distal (Unit IV2) depositional setting, and may also account for the slightly improved permeability-porosity in the Unit IV-1 versus Unit IV-2 (Fig. 6A; Table 1).

Within a given stratigraphic unit, the higher permeability Group A samples are coarser grained than the Group B sandstones (comparing Unit IV-3 and Unit IV-1 in Figs. 11 and 12). However, medium grained Group B samples (8 samples) exhibit poorer permeability than the equivalent grain size Group A samples due to: (a) quartz cement occluding porosity in proximity to stylolites, (b) higher clay content (15\%) not taken into account in grain size measurement (only 1 sample), and/or (c) pore-filling fibrous illite and/or pyrite and kaolinite. The fine to medium grained Unit IV-3 sandstones within Group B with visible intergranular porosity (1.5-5.0\%) and no feldspar (16 samples), may represent the lower permeability transition into the Group A facies.

\subsection{Detrital Mineralogy}

\subsubsection{Group A}

The present-day detrital composition of the Group A samples is dominated by quartz (97.2-100\%) with no feldspar content and minor lithic fragments (Table 2), and hence all are classified as quartzarenites (Fig. 13). Quartz grains are classified as monocrystalline $\left(\mathrm{Q}_{\mathrm{m}}\right)$ $(65-83 \%)$ or as polycrystalline $\left(\mathrm{Q}_{\mathrm{p}}\right)(0.3-7 \%)$ according to the number of domains within the grain in cross nicols. Polycrystalline quartz content $>4 \%$ is most common in the medium to coarse grained Group A sandstones of the Unit IV-3. A metamorphic to igneous source can 
1 be implied by monocrystalline quartz, while a low grade metamorphic source is suggested by 2 polycrystalline quartz grain textures (Pettijohn et al., 1987), possibly indicating provenance

3 from the Proterozoic basement.

4

Lithic fragments are present in nine samples (0.3-2\%) and range from grey to yellowish-brown, rigid to deformed, claystone clasts (7 samples) and deformed schistose metamorphic fragments ( 2 samples). Preserved feldspar is rare and only present in one Group A sample (Fig. 14A) in minor amounts (0.3\%). Non-birefringent matrix clay ranges between $0.7-4.0 \%$ (18 samples), and an increase in clay generally lowers the permeability and quartz cement volume. Heavy minerals such as apatite, tourmaline and zircon are present in trace amounts. Rare ooids display radial fibrous extinction, and can be replaced by illite, iron oxides or partially dissolved into secondary porosity.

\subsubsection{Group B}

The Group B sandstones range in composition from subarkosic to quartzarenitic with detrital quartz contents between $90-100 \%$, but generally $>98 \%$ (Fig. 13). Quartz is present as monocrystalline grains (50-79\%; all samples) and as polycrystalline quartz $(0.3-8.7 \% ; 42$ samples). The highest polycrystalline quartz contents in this sub-group is found in the Unit IV-3. Preserved feldspar (trace-6.3\%; 15 samples) is predominantly potassium feldspar with trace plagioclase.

Preserved feldspar content in the Unit IV-3 of Group B is generally low $(<0.3 \%$; 4 samples) with the exception of one outlier sample that is rich in primary clay (14.7\%) and feldspar (6.3\%) (Figs. 12D, 14A). The depositional feldspar content of the sandstones was subsequently estimated in the diagenetic models by assuming a closed chemical system and that the aluminium (Al) content in the authigenic illite and kaolinite was derived from the initial feldspar content. Results show feldspar and lithics were likely more abundant in the poorer quality Group B sandstones at deposition compared to Group A sandstones (Fig. 13) and leads to a reclassification of many Group B quartzarenites as subarkoses.

Preserved lithic fragments consist of undeformed to deformed sedimentary rock fragments $(0.3-1.3 \%$; 29 samples) and occasional micaceous metamorphic fragments (0.3$1.3 \% ; 10$ samples). Initial lithic content was visually estimated to be between $0.3-4.7 \%$ (39 samples). Muscovite content $(0.3-2.7 \%$; 20 samples $)$ generally increases with initial feldspar 
content, and suggests either shared granitic or schistose provenance or the preferential concentration of lower density grains within finer-grained deposits. Yellowish-brown non- to low-birefringent matrix clay ranges from $0.3-14.7 \%$ (18 samples). The clay can be partially replaced by pyrite, fibrous illite and Fe-oxides, and is sometimes concentrated along pressure solution boundaries or stylolites.

\subsection{Authigenic Mineralogy}

\subsubsection{Grain Coating Phases}

Grain coating phases are known to preserve reservoir quality during burial due to the blocking of nucleation sites for subsequent cement phases such as quartz (e.g. Heald and Larese, 1974; Bloch et al., 2002). Grain coat clay coverage was measured on 100 grains of each thin section to evaluate the impact on quartz cement nucleation. Group A samples have an average clay coat range of $15-42 \%$, and Group B samples have a wider average of 8-79\% (Table 2). In this sample set, non- to low-birefringent clay occurs as thin discontinuous rims around quartz grains, and can be partially altered to cuboid pyrite (P1), rounded silver-orange iron or titanium oxides, or early illite (I1). Clay rims were almost always discontinuous around each grain, but were observed to coat the nucleation surfaces and ultimately stop growth of quartz cement (Fig. 12E). Despite the presence of these coatings, quartz cement nucleating from neighbouring 'uncoated' grains grew into the pore space and enclosed the coated grain and early authigenic phases (e.g. P1, I1), indicating that grain coat coverage was insufficient to significantly preserve reservoir quality.

\subsubsection{Quartz Cement}

Authigenic quartz (Q1) is the dominant pore-filling cement and forms well-developed euhedral faces, filling pore space (Figs. 12, 15A and 15B). The higher permeability Group A sandstones yield quartz cement volumes of $9-22 \%$ (average 14\%), and the lower permeability Group B samples yield volumes of 5-31\% (average 20\%; Table 2). Syntaxial quartz cement that nucleated on clean grain surfaces is more common on monocrystalline quartz $(\mathrm{Qm})$ compared to polycrystalline quartz (Qp). The quartz cement can be observed to stop at the boundaries of rounded adjacent grains that were subsequently dissolved, indicating dissolution (likely feldspar and lithics) occurred after or during quartz precipitation. Rarely, 
there may be remnant clay rim detritus left over after grain dissolution which also may have also inhibited the growth of quartz into the void. Quartz cement can also be seen to grow into mouldic pores, with low volumes ranging from $0.3-1.7 \%$ (4 samples) in Group A and 0.3$1.7 \%$ (19 samples) in Group B. An additional and less significant quartz cement (Q2) appears to post-date the earlier quartz, and appears as a different shade under crossed nicols. Q2 volumes in Group A range from 0.3-1.0\% (4 samples) and Group B volumes range between $0.3-2.7 \%$ (21 samples).

\subsubsection{Illite}

Discontinuous detrital clay coats found on grains are seen to be illitized in $\sim 1 \%$ of samples. ESEM photographs indicate a platey morphology (Fig. 15C) and this likely corresponds to the mixed layer illite-smectite (I/S) identified by XRD. This early illite (I1) is commonly overgrown by quartz cement (Q1). A later phase of illite (I2) is observed to replace matrix clay, feldspar, claystone lithics, and rarely kaolinite, and ESEM photographs indicate a fibrous morphology (Fig. 15D). Pore-filling illite commonly grows in mouldic pore space and is not observed in intergranular pore space, but sometimes illite can be oil-stained when the mouldic pores are connected to intergranular pores. In contrast, isolated mouldic pores tend not to contain heavy hydrocarbon suggesting that the oil did not infiltrate these poorly connected pores. Pore-filling illite (I2) cement volume is low in Group A $(1.0-1.7 \%$; 3 samples). Illite cement (I2) is relatively more abundant in the lower permeability Group B samples ranging from $0.3-12 \%$ (average $2.9 \% ; 30$ samples), and tends to be most abundant within the Group B sandstones with high mouldic porosity (Fig. 14B). Total illite volumes are presented in Table 2.

\subsubsection{Kaolinite}

Two minor phases of kaolinite are observed. The first phase (K1) is relatively early and is seen to be trapped and overgrown by quartz cement (Q1), while the second phase (K2) occurs in small diffuse stacks and occludes mouldic pores. The source of aluminium for kaolinite is likely from feldspar dissolution, which appears to paragenetically post-date Q1 precipitation or occur concurrently (see section 5.3.2), hence, $\mathrm{K} 2$ is interpreted to post-date the Q1 cement. Within the higher permeability Group A sandstones, rare kaolinite cement 
1

ranges from 0.3-1.3\% when present (average 0.8\%; 2 samples; Table 2). Kaolinite cement is only slightly more common in the lower permeability Group B samples ranging from 0.3$7.3 \%$ (average 1.8\%; 7 samples; Table 2), with all of these samples occurring in one well in the southern part of the field.

\subsubsection{Minor Authigenic Phases}

Other relatively minor, but locally important, phases of authigenic minerals include pyrite, Fe- and Ti-oxides, siderite, calcite, ferroan-dolomite and barite. Pyrite is generally persistent throughout all samples, although the highest concentrations tend to be in the Unit IV-3. Early pyrite (P1) is observed as very fine to medium crystalline cuboids replacing detrital clay rims, floating within quartz overgrowths or as poikilotopic 1-5 $\mathrm{mm}$ sized nodules. Replacive pyrite ( $\mathrm{P} 2)$, which is slightly more common than pore-filling pyrite, replaces primary clay or lithics, and can be occasionally concentrated along undulatory clayrich stylolites.

Fe- and Ti-oxides (F1) can replace clay rims, float within the first phase of quartz cement $(\mathrm{Q} 1)$, or occur later in the paragenetic sequence replacing remnant dissolved grains within mouldic porosity (F2).

All authigenic carbonate minerals (ferroan dolomite, calcite and siderite) occur relatively late in the diagenetic sequence. These cements tend to fill mouldic porosity that appears to have formed after the precipitation of the Q1 cement. Carbonate cements can be locally significant in the Group B samples (1-3\%; 5 samples), but are typically absent in the Group A samples.

Barite occurs as fine to coarsely crystalline to poikilotopic cement, and can be within mouldic and intergranular porosity or replacive after primary matrix clay and feldspar. It is mainly observed in the Unit IV-3 sandstone, and encloses all quartz cement phases, as well as bitumen adjacent to quartz cements.

\subsubsection{Solid Bitumen}

Residual heavy hydrocarbon or solid bitumen is identifed as an opaque discontinuous thin coating or pore-throat blocking phase in minor quantities (0.3-4.3\%; Table 2). Bitumen 
can be found in the high permeability Group A sandstones (16 out of 25 samples) and less so in the Group B sandstones (15 out of 45 samples; Table 2). Residual heavy hydrocarbon stains early kaolinite and illite phases and coats euhedral quartz cement (Q1) within intergranular pore space. The bitumen coating phase is typically 1-5 $\mu \mathrm{m}$ thick and can occur across euhedral quartz cement (Q1) faces, but is generally not continuous around the entire pore. The bitumen coatings may also be overgrown by quartz cement nucleating from an adjacent uncoated quartz surface, seen in samples in the south of the field. Bitumen takes on a shiny-yellow orange appearance in reflected light in samples from the southern part of the field, and the presence of some pyrobitumen here supports an increase in peak burial temperature in the south of the field (English et al., 2016c).

\subsection{Visible Porosity}

The pore system can be petrographically characterized as primary intergranular and mouldic. The higher permeability Group A samples are dominated by primary intergranular porosity (up to $11.3 \%$ ), whereas the lower permeability Group B samples are generally dominated by secondary mouldic porosity (up to 7.0\%) (Fig. 14C; Table 2). The samples dominated by primary intergranular porosity (Fig. 14C) are exclusively fine to coarse grained clean sandstones, and occur most commonly in the Unit IV-3. Visible intergranular porosity is poorly preserved in the very fine grained sandstones and absent in the siltstones. Good permeability correlates to original primary intergranular porosity where quartz cementation is incomplete and pore-filling illite cements are very low $(<0.5 \%)$. "Oversized" secondary pores appear to have been created by full dissolution of unstable grains within an intergranular porosity dominated network.

In the finer-grained, and often more feldspathic sandstones, the intergranular pore space is occluded by authigenic quartz and illite, and more commonly characterized by the presence of isolated mouldic pores interpreted to result from the dissolution of K-feldspar and lithic clasts. These secondary mouldic pores are observed to be poorly connected, and while they may locally give rise to reasonable porosity (up to $11 \%$, Fig. 14C), the permeability of these sandstones is invariably low. Microporosity, contained within primary clay, clay-rich grains, and illite and kaolinite masses, likely accounts for the difference between petrographic-derived visual porosity estimates and laboratory core measurements. 
Observations from the petrographic analysis indicate that samples from the southern well (Well G) have higher quartz cement volumes and lower porosity and permeability than compositionally and texturally equivalent samples from the northern area (Fig. 16). The primary focus of the numerical modelling with Touchstone ${ }^{\mathrm{TM}}$ was to investigate the impact of thermal history on the high permeability facies (Group A), and establish if greater thermal exposure may account for the increased level of quartz precipitation in the south.

Group A samples were filtered so that only Unit IV-3 samples of similar characteristics were used (Table 3). Outliers (excess pyrite, mouldic porosity dominant) were removed from the sample set leaving 20 samples. The final subset of Unit IV-3 samples used to calibrate the model was taken from three different wells (Wells A, G, H; Fig. 1). Using separate burial, thermal and effective stress histories for the northern area (Wells A and $\mathrm{H}$ ) and southern area (Well G) (English et al., 2016c) of the field, and a single set of optimized model parameters for all samples, the numerical model was able to achieve a good match between modelled and measured data for IGV, quartz cement, total porosity and permeability (Fig. 17). The details of the model configuration used in this study are provided in Table 3. The model correctly predicts that the samples from the southern well (Well G) will have higher quartz cement volumes and lower porosity and permeability than equivalent samples from the northern area (Fig. 17B, 17C, 17D). This is consistent with observations from the petrographic analysis (Fig. 16). Hence, higher temperatures experienced in the south are interpreted to be the cause of increased quartz cement volume there, while variations in porosity and permeability between the two northern wells (Well $\mathrm{H}$ versus Well A; Figs. 17C, 17D) are interpreted to be primarily due to differences in grain size (i.e. available surface area) (Fig. 16).

The paragenetic sequence is primarily constrained by petrographic observations, and the modelled sequence is displayed in Figure 18. During the pre-Hercynian stage, the greatest degree of compaction, dissolution and re-precipitation of cement occurs, with a higher degree of reservoir quality destruction occurring in the lower permeability Group B samples. Extensive quartz cementation occurred during burial stages in the Carboniferous and Mesozoic (Fig. 18), which continued to degrade the reservoir. Late cement phases such as 
barite are modelled to occur after the onset of Cenozoic exhumation; this interpretation is supported by fluid inclusion data (English et al., 2016a; English et al., 2016c).

Predictive present-day frequency distributions for total porosity and permeability of the Group A lithofacies provide a good match with measured sample distributions (Fig. 19), and also illustrate that spatial variations in thermal history across the field have a major impact on reservoir quality. The evolution of porosity and permeability, compared to thermal history, is illustrated in Figure 20. The predicted present-day mean porosity and geometric mean permeability range from $9.2 \%$ and $131 \mathrm{mD}$ in the north of the field to $4.1 \%$ and $1.1 \mathrm{mD}$ in the south of the field. The P10 to P90 envelope illustrates the likely range of reservoir parameters that could be encountered for the specified thermal history. These averages are within the range of field-wide porosity-permeability data for the Unit IV-3 (Figs. 6A, 17C, 17D).

Finally, the results of the diagenetic models were extrapolated away from the petrographic control wells to generate predicted present-day porosity and permeability maps for the entire study area using $\mathrm{T}>\mathrm{Map}^{\mathrm{TM}}$ software. This modelling step integrates the calibrated frequency distributions for each of the input rock property parameters with a suite of depth, thermal history, and effective stress maps across the study area for 15 different geologic time-steps between time of deposition and present-day. Maximum paleotemperatures across all wells ranged from 137 to $163^{\circ} \mathrm{C}$ with timing of peak temperatures and exhumation the same as Wells A and G (Fig. 3). The resulting mean porosity and geometric mean permeability maps predict that the Group A facies will yield better reservoir quality in the north of the field area because of the shallower maximum burial compared to the more deeply buried southern part of the field with higher peak paleotemperatures (Fig. 21).

\subsection{Discussion}

\subsection{Sedimentological Controls on Ordovician Reservoir Quality}

Upper Ordovician sandstones display highly variable reservoir quality (e.g. Hirst et al., 2002; Hirst, 2012; Wells et al., 2015), from conventional reservoirs through to very low permeability tight gas reservoirs (Fig. 6). This study demonstrates that depositional texture, composition and thermal history are the primary controls on reservoir quality in these 
sandstones. The most permeable facies is found in the post-glacial marine sequence of the Unit IV-3 and proximal deposits of the syn-glacial Unit IV-1, which can yield matrix permeabilities in the range of $0.1 \mathrm{mD}$ up to 1 Darcy (Group A, Fig. 6). This facies comprises fine to coarse grained sandstones (Fig. 10), and is dominated by intergranular porosity with little or no initial detrital feldspar or authigenic illite content (Fig. 14).

In contrast, the lower permeability sandstones (Group $\mathrm{B},<0.1 \mathrm{mD}$ ) typically consist of finer-grained and more feldspathic compositions characterized by the poor preservation of primary intergranular porosity due to quartz cement, and the dominance of poorly-connected mouldic pores and microporosity (Fig. 14C). Significant secondary porosity is likely generated by the dissolution of feldspar and lithics, and these secondary pores often contain pore-filling illite cements. Group B samples are found in all stratigraphic units, but are especially prevalent in the finer-grained and more distal facies of the Unit IV-2 (Fig. 12).

The best quality reservoir is also encountered in the Unit IV-3 in other Ordovician fields in the basin such as Tiguentourine (Lang et al., 2012; Hirst, 2016) and Tin Fouyé Tabankort (Askri et al., 1995; Le Maux et al., 2006). A recent sedimentological study has interpreted these uppermost Ordovician sandstones in the Illizi Basin as being deposited in a high-energy, tidally-influenced, shallow marine environment following a period of postglacial isostatic rebound (Hirst, 2016). The moderate- to high-energy depositional setting was likely to have been a key factor in the deposition of these relatively coarser-grained, clean quartzitic sands. Although these sands have been described as laterally discontinuous at the Tiguentourine field (In Amenas area) and in outcrop (Hirst et al., 2002; Hirst, 2016), they appear to be more laterally continuous at the Tin Fouyé Tabankort field (Askri et al., 1995; Le Maux et al., 2006) and in the current study area. Good reservoir quality has also been encountered in proximal and medial glaciomarine fan sandstones (Unit IV-1 equivalent) in the In Amenas area (Lang et al., 2012; Wells et al., 2015), but this unit is relatively undersampled in this study.

\subsection{Role of Bitumen in Reservoir Quality Preservation}

Indicators that bitumen coats may have locally slowed quartz growth include: (1) bitumen is sometimes observed to coat the main quartz cement phase (Q1), and quartz cement is observed to no longer nucleate from that coated face; (2) bitumen often appears 
between the quartz cement and intergranular pore space; and (3) bitumen is mostly, but not exclusively, observed in permeable rocks. However, bitumen is only present in minor quantities (0.0-2.3\%) in the high permeability Group A samples, and is only present in 16 out of the 25 samples described (Table 2). Where present, the bitumen does not coat every quartz face within a pore (Fig. 12A), and quartz cement continued to grow on the clean quartz faces. In samples with a hotter thermal history in the south of the field, the bitumen can be fully enclosed by quartz cement that has grown from adjacent uncoated quartz grains or faces, suggesting that the presence of bitumen may not have a material impact on reservoir quality. The bitumen is not usually found in the isolated mouldic pores, which suggests that oil more readily penetrated and saturated the primary intergranular pore system. Therefore, it is possible that the bitumen does not play a significant role in the preservation of porosity and permeability in this dataset, but rather highlights (a) the main migration pathways for oil that existed within the reservoir in the past or (b) the presence of local paleo oil columns.

\subsection{Importance of Constraining Thermal History in Exhumed Basins}

Authigenic quartz is the primary pore-filling cement in these quartzitic Ordovician sandstones. Previous studies have shown that quartz cement volume depends on the rate of precipitation and availability of quartz substrates, such as grain surface area (Lander et al., 2008). Based on numerical modelling in this study, higher thermal exposure is interpreted to have been the cause of increased levels of quartz precipitation in the southern part of the study area (Well A versus Well G; Fig. 16), while variations in porosity and permeability between the two northern wells (Well H versus Well A; Figs. 17C, 17D) are interpreted to be primarily due to differences in grain size (i.e. available surface area) (Fig. 16). For a given thermal history, the coarser grained samples are likely to have porosity and permeability values above the mean, while finer grained samples are likely to have lower values. Coarsergrained facies in the southern part of the field are predicted to still retain adequate reservoir characteristics (>1 mD) as indicated by the range in modelled distributions (Fig. 20).

However, the key implication of this detailed analysis is that reservoir quality in clean quartzitic sandstones is inherently linked to length of exposure to elevated burial temperatures. A difference only $16^{\circ} \mathrm{C}$ in peak paleotemperature across the study area, over a significant amount of time ( $250 \mathrm{My}$; Fig. 18), has led to a material difference in reservoir quality. Therefore, it is of critical importance to identify and evaluate subtle differences in 
thermal history across a basin, whether caused by differential burial or variable heat flow etc., in order to predict regions of better reservoir quality and deliverability. This is particularly critical in exhumed basins where variations in present-day burial depth will be a poor guide for evaluating the variation in reservoir quality risk across a basin or play (e.g. note the discordance between present-day burial depth and predicted permeability in Figure 21). Further refinement of the reservoir model in this study will require additional wells and detailed sedimentological models to predict variations in primary depositional facies and thicknesses across the field. Additionally, natural fractures can also augment the bulk permeability of the sandstones, which is especially important in the tighter reservoir rocks.

\subsection{Conclusions}

This study constitutes a detailed integration of the tectonic evolution, thermal history and petrographic characterization of the Upper Ordovician sandstone sequence to (1) determine the main controls on reservoir quality and (2) predict 'sweet spots' for enhanced productivity. This study also incorporates a number of diverse analytical and modelling techniques including thermal maturity, apatite fission-track, sonic compaction analysis, fluid inclusions, 1D basin modelling, petrography, core analysis, facies characterization, and predictive reservoir quality modelling. The integrated workflow presented within this study could be replicated in other reservoirs and basins to enhance the identification of subtle, yet commercially significant, spatial and vertical trends in thermal history and reservoir quality.

The main findings of this study are as follows:

- Depositional texture and composition are important controls on reservoir quality. The best reservoir quality is encountered in the post-glacial marine sequence of the Unit IV-3, where fine to coarse grained quartzarenites are dominated by intergranular porosity with little or no initial detrital feldspar or authigenic illite content.

- Poorer quality reservoir sandstones typically consist of finer-grained and more feldspathic compositions with poor preservation of primary intergranular porosity, and, hence, lower permeability.

- Increased quartz cement volume in Unit IV-3 samples from the southern part of the field is interpreted to have resulted from increased thermal exposure during deeper burial. 
- Thermal history has a material impact on the spatial variability of reservoir permeability, and this study demonstrates that relatively minor differences in thermal history can make a significant difference to the reservoir quality. This is a particularly important consideration in reservoir quality studies in exhumed basins where variations in present-day burial depth will be a poor guide for evaluating reservoir quality risk across a basin or play. 


\section{References}

Ajdukiewicz, J.M., and Lander, R.H., 2010, Sandstone reservoir quality prediction: The state of the art: American Association of Petroleum Geologists Bulletin, v. 94, p. 1083-1091, doi: $\underline{10.1306 / \text { intro060110. }}$.

Aliev, M., Aït Laoussine, N., Avrov, V., Aleksine, G., Barouline, G., Lakovlev, B., Korj, M., Kouvykine, J., Makarov, V., Mazanov, V., Medvedev, E., Mkrtchiane, O., Moustafinov, R., Oriev, L., Oroudjeva, D., Oulmi, M., and Saïd, A., 1971, Geological structures and estimation of oil and gas in the Sahara in Algeria: Spain, AltamiraRotopress, S.A., 265 p.

Armstrong, H.A., and Coe, A., 1997, Deep-sea sediments record the geophysiology of the late Ordovician glaciation: Journal of the Geological Society of London, v. 154, 929934, doi: $10.1144 /$ gsjgs.154.6.0929.

Askri, H., Belmecheri, A., Benrabah, B., Boudjema, A., Boumendjel, K., Daoudi, M., Drid, M., Ghalem, T., Docca, A.M., Ghandriche, H., Ghomari, A., Guellati, N., Khennous, M., Lounici, R., Naili, H., Takherist, D., and Terkmani, M., 1995, Géologie de l'Algérie (Geology of Algeria): Bath, UK, Schlumberger-Sonatrach Well Evaluation Conference 1995, 93 p.

Bennacef, A., Beuf, S., Biju-Duval, B., de Chapal, O., Gariel, O., and Rognon, P., 1971, Example of cratonic sedimentation: Lower Paleozoic of Algerian Sahara: American Association of Petroleum Geologists Bulletin, v. 55, p. 2225-2245.

Beuf, S., Biju-Duval, B., de Chapal, O., Rognon, P., Gariel, O., and Bennacef, A., 1971, Les grès du Paléozoïque inférieur au Sahara: Paris, Publications de l'Institut Français du Pétrole, Coll. Science et Technique du Pétrole 18, 464 p.

Bjørkum, P.A., Oelkers, E.H., Nadeau, P.H., Walderhaug, O., and Murphy, W.M.., 1998, Porosity prediction in quartzose sandstones as a function of time, temperature, depth, stylolite frequency, and hydrocarbon saturation: American Association of Petroleum Geologists Bulletin, v. 82, p. 637-648.

Bloch, S., Lander, R.H., and Bonnell, L., 2002, Anomalously high porosity and permeability in deeply buried sandstone reservoirs: Origin and predictability: American Association of Petroleum Geologists Bulletin, v. 86, p. 301-328, doi: 10.1306/61EEDABC-173E11D7-8645000102C1865D. 
Boote, D.R.D., Clark-Lowes, D.D., and Traut, M.W., 1998, Palaeozoic petroleum systems of North Africa, in MacGregor, D.S., Moody, R.T.J., and Clark-Lowes, D.D., eds., Petroleum geology of North Africa: Geological Society, London, Special Publication 132, p. 7-68, doi: 10.1144/GSL.SP.1998.132.01.02.

Bonnell, L.M., Warren, E.H., and Lander, R.H., 1998, Reservoir quality prediction through simulation of sandstone diagenesis: Cusiana field, eastern Columbia: Abstract, International AAPG Conference and Exhibition, Rio de Janeiro, Brazil, AAPG Bulletin, v. 82, p. 1894.

Bonnell, L.M., Lowrey, C.J., and Bray, A.A., 1999, The timing of illitization, Haltenbanken, mid-Norway: Abstract, American Association of Petroleum Geologists Annual Meeting Program, v. 8, p. A14.

Bonnell, L.M., Lander, R.H., and Matthews, J.C., 2000, Probabilistic prediction of reservoir quality in deep water prospects using an empirically calibrated process model: Abstract, American Association of Petroleum Geologists Annual Meeting Program, v. 9, p. A15.

Boudjema, A., 1987, Evolution structural du basin petrolier Triasique du Sahara Nord Oriental (Algérie): Ph.D. thesis, Université de Paris-Sud, Centre d'Orsay, 290 p.

Brenchley, P.J., Marshall, J.D., Carden, G.A.F., Robertson, D.B.R., Long, D.G.F., Meidla, T., Hintes, L., Anderson, T.F., 1994, Bathymetric and isotopic evidence for a short-lived late Ordovician glaciation in a greenhouse period: Geology, v. 22, p. 295-298, doi: 10.1130/0091-7613(1994)022<0295:BAIEFA>2.3.CO;2.

Busch, B., Hilgers, C., Lander, R.H., Bonnell, L.M., and Adelmann, D., in press, Reservoir quality and burial model evaluation by kinetic quartz and illite cementation modeling: case study Rotliegend, N-Germany: American Association of Petroleum Geologists Bulletin.

Denis, M., Buoncristiani, J.-F., Konaté, M., Ghienne, J.-F., and Guiraud, M., 2007, Hirnantian glacial and deglacial record in SW Djado Basin (NE Niger): Geodinámica Acta, v. 20, p. 177-195, doi: 10.3166/ga.20.177-195.

Deschamps, R., Eschard, R., and Roussé, S., 2013, Architecture of Late Ordovician glacial valleys in the Tassili N'Ajjer area (Algeria): Sedimentary Geology, v. 289, p. 124-147, doi: $\underline{10.1016 / \text { j.sedgeo.2013.02.012. }}$. 
Destombes, J., Holland, H., and Willefert, S., 1985, Lower Palaeozoic rocks of Morocco, in Holland, C.H., ed., Lower Palaeozoic Rocks of the World: Wiley, London, p. 91-336.

Dixon, R.J., Patton, T.L., and Hirst, J.P.P., 2008a, Giant sandwaves from the Late Ordovician of the Tassili N'Ager, Algeria: Extended Abstract, Marine and River Dune Dynamics, 1-3 April 2008, Leeds, UK, p. 75-78.

Dixon, R.J., Patton, T.L., Hirst, J.P.P., and Diggens, J., 2008b, Transition from subglacial to proglacial depositional systems: Implications for reservoir architecture, Illizi Basin, Algeria: AAPG Search and Discovery, article 50095, http://www.searchanddiscovery.com/documents/2008/08180dixon/dixon-50095.pdf (accessed December 10th, 2014).

Dixon, R.J., Moore, J.K.S., Bourne, M., Dunn, E., Haig, D.B., Hossack, J., Roberts, N., Parsons, T., and Simmons, C.J., 2010, Integrated petroleum systems and play fairway analysis in a complex Palaeozoic basin: Ghadames-Illizi Basin, North Africa: Geological Society, London, Petroleum Geology Conference series 7, p. 735-760, doi: $\underline{10.1144 / 0070735 .}$.

Echikh, K., 1998, Geology and hydrocarbon occurrences in the Ghadames Basin, Algeria, Tunisia, Libya, in MacGregor, D.S., Moody, R.T.J., and Clark-Lowes, D.D., eds., Petroleum Geology of North Africa: Geological Society, London, Special Publication 132, p. 109-129, doi: 10.1144/GSL.SP.1998.132.01.06.

English, K.L., English, J.M., Redfern, J., Hollis, C., Corcoran, D.V., Oxtoby, N., and Yahia Cherif, R., 2016a, Remobilization of deep basin brine during exhumation of the Illizi Basin, Algeria: Marine and Petroleum Geology, doi: 10.1016/j.marpetgeo.2016.08.016.

English, K.L., Redfern, J., Bertotti, G., English, J.M., and Yahia Cherif, R., 2016b, Intraplate uplift: New constraints on the Hoggar dome from the Illizi basin (Algeria): Basin Research, doi: $10.1111 / \mathrm{bre} .12182$.

English, K.L., Redfern, J., Corcoran, D.V., English, J.M., and Yahia Cherif, R., 2016c, Constraining burial history and petroleum charge in exhumed basins: new insights from the Illizi Basin: American Association of Petroleum Geologists Bulletin, v. 100, p.623655, doi: $10.1306 / 12171515067$. 
1 Eschard, R., Abdallah, H., Braik, F., and Desaubliaux, G., 2005, The Lower Paleozoic succession in the Tassili outcrops, Algeria: sedimentology and sequence stratigraphy: First Break, v. 23, p 27-36.

Fabre, J., 1976, Introduction à la géologie du Sahara algérien et des régions voisines: Algiers, Algeria, Société Nationale d'Édition et de Diffusion, 422 p.

Folk, R.L., 1974, Petrology of Sedimentary Rocks: Texas, Hemphill Publication Company, $170 \mathrm{p}$.

Galeazzi, S., Point, O., Haddadi, N., Mather, J., and Druesne, D., 2010, Regional geology and petroleum systems of the Illizi-Berkine area of the Algerian Saharan Platform: An overview: Marine and Petroleum Geology, v. 27, p. 143-178, doi: 10.1016/j.marpetgeo.2008.10.002.

Ghienne, J.-F., and Deynoux, M., 1998, Large-scale channel fill structures in Late Ordovician glacial deposits in Mauritania, western Sahara: Sedimentary Geology, v. 119, p. 141159, doi: 10.1016/S0037-0738(98)00045-1.

Ghienne, J.-F., Boumendjel, K., Paris, F., Videt, B., Racheboeuf, P., and Salem, H.A., 2007a, The Cambrian-Ordovician succession in the Ougarta Range (western Algeria, North Africa) and interference of the Late Ordovician glaciation on the development of the Lower Palaeozoic transgression on northern Gondwana: Bulletin of Geosciences, v. 82, p. 183-214, doi: 10.3140/bull.geosci.2007.03.183.

Ghienne, J.-F., Le Heron, D.P., Moreau, J., Denis, M., and Deynoux, M., 2007b, The Late Ordovician glacial sedimentary system of the North Gondwana Platform, in Hambrey, M.J., Christoffersen, P., Glasser, N.F., and Hubbard, B., eds., Glacial sedimentary processes and products: Blackwell Publishing Ltd., Oxford, p. 295-319, doi: $\underline{10.1002 / 9781444304435 . \operatorname{ch} 17 .}$.

Ghienne, J.-F., Moreau, J., Degermann, L., and Rubino, J.-L., 2013, Lower Palaeozoic unconformities in an intracratonic platform setting: glacial erosion versus tectonics in the eastern Murzuq Basin (southern Libya): International Journal of Earth Sciences, v. 102, p. 455-482, doi: 10.1007/s00531-012-0815-y.

Girard, F., Ghienne, J.-F., and Rubino, J.-L., 2012, Channelized sandstone bodies ('Cordons') in the Tassili N'Ajjer (Algeria and Libya): snapshots of a Late Ordovician proglacial outwash plain, in Huuse, M., Redfern, J., Le Heron, D.P., Dixon, R.J., Moscariello, A., 
and Craig, J., eds., Glaciogenic reservoir and hydrocarbon systems: An introduction: Geological Society of London, London, Special Publications, 368, p. 355-379, doi: $\underline{10.1144 / \mathrm{SP} 368.3 .}$.

Grabowski Jr., G.J., 2005, Sequence stratigraphy and distribution of Silurian organic-rich "hot shales" of Arabia and North Africa: International Petroleum Technology Conference, IPTC-10388-ABSTRACT, doi: 10.2523/10388-ABSTRACT.

Guiraud, R., Bosworth, W., Thierry, J., and Delplanque, A., 2005, Phanerozoic geological evolution of northern and central Africa: An overview: Journal of African Earth Sciences, v. 43, p. 83-143, doi: 10.1016/j.jafrearsci.2005.07.017.

Haddad, S., Smalley, C., and Hutchison, A., 2005, Reservoir quality modelling in CambroOrdovician sands of the Tiguentourine gas field, Illizi Basin, Algeria (abs.): EAGE $2^{\text {nd }}$ North African/Mediterranean Petroleum \& Geosciences Conference \& Exhibition, Algiers, 10-13 April 2005.

Hambrey, M.J., 1985, The Late Ordovician - Early Silurian glacial period: Palaeogeography, Palaeoclimatology, Palaeoecology, v. 51, p. 273-289, doi: 10.1016/00310182(85)90089-6.

Hartmann, D.J., and Beaumont, E.A., 1999, Predicting reservoir system quality and performance, in Beaumont, E.A., and Foster, N.H., eds., Exploring for oil and gas traps - Treatise of petroleum geology: American Association of Petroleum Geologists Treatise of Petroleum Geology, chapter 9, p. 9-1- 9-54.

Heald, M.T., and Larese, R.E., 1974, Influence of coatings on quartz cementation: Journal of Sedimentary Petrology, v. 44, p. 1269-1274, doi: 10.1306/212F6C94-2B24-11D7$\underline{8648000102 \mathrm{C} 1865 \mathrm{D} .}$

Helset, H.M., Lander, R.H., Matthews, J.C., Reemst, P., Bonnell, L.M., and Frette, I., 2002, The role of diagenesis in the formation of fluid overpressures in clastic rocks, in Koestlerand, A.G., and Hunsdale, R., eds., Hydrocarbon seal quantification: Norwegian Petroleum Society Conference, Special Publication 11, p. 37-50, doi: 10.1016/S0928-8937(02)80005-4.

Hirst, J.P., 2012, Ordovician proglacial sediments in Algeria: insights into controls on hydrocarbon reservoirs in the In Amenas field, Illizi basin, in Huuse, M., Redfern, J., Le Heron, D.P., Dixon, R.J., Moscariello, A., and Craig, J., eds., Glaciogenic reservoir 
and hydrocarbon systems: An introduction: Geological Society of London, London, Special Publications, 368, p. 319-353, doi: 10.1144/SP368.17.

Hirst, J.P.P., 2016, Ordovician shallow-marine tidal sandwaves in Algeria - the application of coeval outcrops to constrain the geometry and facies of a discontinuous, high-quality gas reservoir, in Bowman, M., Smyth, H.R., Good, T.R., Passey, S.R., Hirst, J.P.P., and Jordan, C.J., eds., The value of outcrop studies in reducing subsurface uncertainty and risk in hydrocarbon exploration and production: Geological Society of London Special Publication 436, doi: 10.1144/SP436.11.

Hirst, J.P.P., Benbakir, A., Payne, D.F., and Westlake, I.R., 2002, Tunnel valleys and density flow processes in the Upper Ordovician glacial succession, Illizi Basin, Algeria: influence on reservoir quality: Journal of Petroleum Geology, v. 25, p. 297-324, doi: 10.1111/j.1747-5457.2002.tb00011.x.

Hyodo, A., Kozdon, R., Pollington, A.D., and Valley, J.W., 2014, Evolution of quartz cementation and burial history of the Eau Claire Formation based on in situ oxygen isotope analysis of quartz overgrowths: Chemical Geology, v. 384, p. 168-180, doi: 10.1016/j.chemgeo.2014.06.021.

Kaced, M., 2003, Diagenesis of Ordovician Sandstones from the Ahnet Basin, Algeria (abs.): American Association of Petroleum Geologists Search and Discovery, article 90016, http://www.searchanddiscovery.com/abstracts/pdf/2003/hedberg_algeria/allabstracts/nd x_Kaced01.pdf (accessed December 29th, 2015).

Konaté, M., Lang, J., Guiraud, M., Yahaya, M., Denis, M., and Alidou, S., 2006, Un bassin extensif formé pendant la fonte de la calotte glaciaire hirnantienne: le bassin ordovicosilurien de Kandi (Nord Bénin, Sud Niger): Africa Geoscience Review, v. 13, p. 157183.

Lander, R.H., and Bonnell, L.M., 2010, A model for fibrous illite nucleation and growth in sandstones: American Association of Petroleum Geologists Bulletin, v. 94, p. 11611187, doi: $10.1306 / 04211009121$.

Lander, R.H., and Laubach, S.E., 2015, Insights into rates of fracture growth and sealing from a model for quartz cementation in fractured sandstones: Geological Society of America Bulletin, v. 127, p. 516-538, doi: 10.1130/B31092.1. 
Lander, R.H., and Walderhaug, O., 1999, Predicting porosity through simulating sandstone compaction and quartz cementation: American Association of Petroleum Geologists Bulletin, v. 83, p. 433-449.

Lander, R.H., Larese, R.E., and Bonnell, L.M., 2008, Toward more accurate quartz cement models: The importance of euhedral versus noneuhedral growth rates: American Association of Petroleum Geologists Bulletin, v. 92, p. 1537-1563, doi: $\underline{10.1306 / 07160808037 .}$

Lander, R.H., Solano-Acosta, W., Thomas, A.R., Reed, R.M., Kacewicz, M., Bonnell, L.M., and Hooker, J., 2009, Simulation of fault sealing from quartz cementation within cataclastic deformation zones: AAPG Search and Discovery, article 90091, AAPG Hedberg Research Conference, May 3-7, 2009, Napa, California, U.S.A.

Lander, R.H., Walderhaug, O., and Bonnell, L.M., 1997, Application of sandstone diagenetic modeling to reservoir quality prediction and basin history assessment: Memorias del I Congreso Latinoamericano de Sedimentología, Venezolana de Geólogos Tomo I, p. 373-386.

Lang, J., Dixon, R.J., Le Heron, D., and Winsemann, J., 2012, Depositional architecture and sequence stratigraphic correlation of Upper Ordovician glaciogenic deposits, Illizi Basin, Algeria, in Huuse, M., Redfern, J., Le Heron, D.P., Dixon, R.J., Moscariello, A., and Craig, J., eds., Glaciogenic reservoir and hydrocarbon systems: An introduction: Geological Society of London, London, Special Publications, 368, p. 293-317, doi: 10.1144/SP368.1.

Legrand, P., 2003, Paléogéographie du Sahara algérien à l'Ordovicien terminal et au Silurien inférieur: Bulletin Société Géologique de France, v. 174, p. 19-32.

Le Heron, D.P., 2007, Late Ordovician glacial record of the Anti-Atlas, Morocco: Sedimentary Geology, v. 201, p. 93-110, doi: 10.1016/j.sedgeo.2007.05.004.

Le Heron, D.P., and Craig, J., 2008, First order reconstructions of a Late Ordovician Saharan ice sheet: Journal of the Geological Society, v. 165, p. 19-29, doi: 10.1144/001676492007-002.

Le Heron, D.P., Sutcliffe, O.E., Bourgig, K., Craig, J., Visentin, C., and Whittington, R., 2004, Sedimentary architecture of Upper Ordovician tunnel valleys, Gargaf Arch, 
Libya: implications for the genesis of a hydrocarbon reservoir: GeoArabia, v. 9, p. 137160.

Le Heron, D.P., Craig, J., Sutcliffe, O.E., and Whittington, R., 2006, Late Ordovician glaciogenic reservoir heterogeneity: an example from the Murzuq Basin, Libya: Marine and Petroleum Geology, v. 23, p. 655-677, doi: 10.1016/j.marpetgeo.2006.05.006.

Le Heron, D.P., Ghienne, J.-F., El Houicha, M., Khoukhi, Y., and Rubino, J.-L., 2007, Maximum extent of ice sheets in Morocco during the Late Ordovician glaciation: Palaeogeography, Palaeoclimatology, Palaeoecology, v. 245, p. 200-226, doi: 10.1016/j.palaeo.2006.02.031.

Le Heron, D.P., Craig, J., and Etienne, J.L., 2009, Ancient glaciations and hydrocarbon accumulations in North Africa and the Middle East: Earth-Science Reviews, v. 93, p. 47-76, doi: 10.1016/j.earscirev.2009.02.001.

Le Heron, D.P., Armstrong, H.A., Wilson, C., Howard, J.P., Gindre, L., 2010, Glaciation and deglaciation of the Libyan desert: the Late Ordovician record: Sedimentary Geology, v. 223, p. 100-125, doi: 10.1016/j.sedgeo.2009.11.002.

Le Maux, T., Murat, B., Chauveau, A., Amamra, M., and Mesdour, K., 2006, The challenges of building up a geological and reservoir model of a Late Ordovician glaciomarine gas reservoir characterised by the presence of natural fractures: Society of Petroleum Engineers, SPE-101208-MS, doi: 10.2118/101208-MS.

Lewis, J., Clinch, S., Meyer, D., Richards, M., Skirius, C., Stokes, R., and Zarra, L., 2007, Exploration and appraisal challenges in the Gulf of Mexico deep-water Wilcox: Part 1 Exploration overview, reservoir quality, and seismic imaging, in Kennan, L., Pindell, J., and Rosen, N., eds., The Paleogene of the Gulf of Mexico and Caribbean basins: Processes, events, and petroleum systems: 27th Annual GCSSEPM Foundation Bob. F. Perkins Research Conference, December 2-5, Houston, Texas, pp. 398-414.

Liégeois, J.P., Benhallou, A., Azzouni-Sekkal, A., Yahiaouni, R., and Bonin, B., 2005, The Hoggar swell and volcanism: Reactivation of the Precambrian Tuareg shield during Alpine convergence and West African Cenozoic volcanism, in Foulger, G.R., Natland, J.H., Presnall, D.C., and Anderson, D.L., eds., Plates, plumes and paradigms: Geological Society of America Special Paper 388, p. 379-400, doi: 10.1130/0-81372388-4.379. 
1 Lüning, S., Craig, J., Loydell, D.K., Štorch, P., and Fitches, B., 2000, Lower Silurian 'hot shales' in North Africa and Arabia: regional distribution and depositional model: Earth Science Reviews, v. 49, p. 121-200, doi: 10.1016/S0012-8252(99)00060-4.

Makowitz, A, Lander, R.H., and Milliken, K.L., 2006, Diagenetic modelling to assess the relative timing of quartz cementation and brittle grain processes during compaction: American Association of Petroleum Geologists Bulletin, v. 90, p. 873-885, doi: $\underline{10.1306 / 12190505044 .}$.

Makowitz, A, Lander, R.H., and Milliken, K.L., 2010, Chemical diagenetic constraints on the timing of cataclasis in deformed sandstone along the Pine Mountain overthrust, eastern Kentucky: Journal of Structural Geology, v. 32, p. 1923-1932, doi: 10.1016/j.jsg.2010.04.014.

Morantes, J.M., 2003, Quartz cementation modeling and reservoir quality of the Upper Cretaceous sandstones in Carito field, north Monagas, Venezuela: M.Sc. thesis, University of Texas at Austin, $183 \mathrm{p}$.

Moreau, J., Ghienne, J.-F., Le Heron, D., Rubino, J.-L., and Deynoux, M., 2005, 440 ma old ice stream in North Africa: Geology, v. 33, p. 753-756, doi: 10.1130/G21782.1.

Moreau, J., 2011, The Late Ordovician deglaciation sequence of the SW Murzuq Basin (Libya): Basin Research, v. 23, p. 449-477, doi: 10.1111/j.1365-2117.2010.00499.x.

Panda, M.N., and Lake, L.W., 1994, Estimation of single phase permeability from parameters of particle-size distribution: American Association of Petroleum Geologists Bulletin, v. 78, p. 1028-1039.

Panda, M.N., and Lake, L.W., 1995, A physical model of cementation and its effects on single-phase permeability: American Association of Petroleum Geologists Bulletin, v. 79 , p. 431-443.

Paxton, S.T., Szabo, J.O., Ajdukiewicz, J.M., and Klimentides, R.E., 2002, Construction of an intergranular compaction curve for evaluating and predicting compaction and porosity loss in rigid grained sandstone reservoirs: American Association of Petroleum Geologists Bulletin, v. 86, p. 2047-2067. 
Perez, R.J., and Boles, J.R., 2006, An empirically derived kinetic model for albitization of detrital plagioclase: American Journal of Science, v. 305, p. 312-343, doi: 10.2475/ajs.305.4.312.

Perez, R.J., Chatellier, J.I., and Lander, R.H., 1999, Use of quartz cementation kinetic modeling to constrain burial histories; examples from the Maracaibo Basin, Venezuela: Revista Latino-Americana de Geoquimica Organica, v. 5, p. 39-46.

Pettijohn, F.J., Potter, P.E., and Siever, R., 1987, Sand and Sandstone, $2^{\text {nd }}$ Edition, Springerscience and Business Media, New York, USA, 553 p.

Philippe, G., Cave, A., Khemissa, H., and Murat, B., 2003, Late Ordovician (Unit IV Interval) reservoir characterization from the Ohanet/In Adaoui fields, Algeria (abs.): American Association of Petroleum Geologists Search and Discovery, article 90016, http://www.searchanddiscovery.com/abstracts/pdf/2003/hedberg_algeria/allabstracts/nd X_Philippe01.pdf (accessed December 10th, 2014).

Pittman, E.D., and Larese, R.E., 1991, Compaction of lithic sands: Experimental results and applications: American Association of Petroleum Geologists Bulletin, v. 75, p. 12791299.

Powell, J.H., Khalil, M.B., and Masri, A., 1994, Late Ordovician-Early Silurian glaciofluvial deposits preserved in palaeovalleys in South Jordan: Sedimentary Geology, v. 89, p. 303-314, doi: 10.1016/0037-0738(94)90099-X.

Roduit, N., 2006, JMicroVision: Image analysis toolbox for measuring and quantifying components of high-definition images, version 1.2.7, http://www.jmicrovision.com (accessed 5 June 2014).

Rougier, S., Missenard, Y., Gautheron, C., Barbarand, J., Zeyen, H., Pinna, R., Liégeois, J.P., Bonin, B., Ouabadi, A., El-Messaoud Derder, M., and Frizon de Lamotte, D., 2013, Eocene exhumation of the Tuareg Shield (Sahara Desert, Africa): Geology, v. 41, p. 615-618, doi: 10.1130/G33731.1.

Roussé, S., Sandvik, S.E., Murat, B., Hutchinson, A., Saadi, K., and Le Guerroué, E., 2009, Depositional model and allostratigraphic architecture of Late Ordovician syn-glacial strata from the Tiguentourine Field (Illizi Basin, Algeria): Extended Abstract, 8th PESGB/HGS Conference on African E\&P, London, Sept. 
1 Shanley, K.W., Cluff, R.M., and Robinson, J.W., 2004, Factors controlling prolific gas production from low-permeability sandstone reservoirs: Implications for resource assessment, prospect development, and risk analysis: American Association of Petroleum Geologists Bulletin, v. 88, p. 1083-1121, doi: 10.1306/03250403051.

Shanley, K.W., and Cluff, R.M., 2015, The evolution of pore-scale fluid-saturation in lowpermeability sandstone reservoirs: American Association of Petroleum Geologists Bulletin, v. 99, p. 1957-1990, doi: 10.1306/03041411168.

Stampfli, G.M., and Borel, G.D., 2002, A plate tectonic model for the Paleozoic and Mesozoic constrained by dynamic plate boundaries and restored synthetic oceanic isochrons: Earth and Planetary Science Letters, v. 196, p. 17-33, doi: 10.1016/S0012$\underline{821 X(01) 00588-X}$.

Sutcliffe, O.E., Dowdeswell, J.A., Whittington, R.J., Theron, J.N., and Craig, J., 2000, Calibrating the Late Ordovician glaciation and mass extinction by the eccentricity cycles of Earth's orbit: Geology, v. 28, p. 967-970, doi: 10.1130/0091-7613(2000) 28<967:CTLOGA $>2.0$. CO;2.

Taylor, T.R., Giles, M.R., Hathon, L.A., Diggs, T.N., Braunsdorf, N.R., Birbiglia, G.V., Kittridge, M.G., Macaulay, C.I., and Espejo, I.S., 2010, Sandstone diagenesis and reservoir quality prediction: Models, myths, and reality: American Association of Petroleum Geologists Bulletin, v. 94, p. 1093-1132, doi: 10.1306/04211009123.

Taylor, T.R., Kittridge, M.G., Winefield, P., Taras Bryndzia, L., and Bonnell, L.M., 2015, Reservoir quality and rock properties modeling - Triassic and Jurassic sandstones, greater Shearwater area, UK Central North Sea: Marine and Petroleum Geology, v. 65, p. 1-21, doi: 10.1016/j.marpetgeo.2015.03.020.

Taylor, T.R., Stancliffe, R., Macaulay, C., and Hathon, L., 2004, High temperature quartz cementation and the timing of hydrocarbon accumulation in the Jurassic Norphlet sandstone, offshore Gulf of Mexico, USA, in Cubitt, J.M., England, W.A., and Larter, S., eds., Understanding petroleum reservoirs: towards and integrated reservoir engineering and geochemical approach: Geological Society of London Special Publication 237, p. 257-278, doi: 10.1144/GSL.SP.2004.237.01.15.

Tobin, R.C., and Schwarzer, D., 2014, Effects of sandstone provenance on reservoir quality preservation in the deep subsurface: experimental modelling of deep-water sand in the 
Gulf of Mexico, in Scott, R.A., Smyth, H.R., Morton, A.C., and Richardson, N., eds., Sediment provenance studies in hydrocarbon exploration and production: Geological Society of London Special Publication 386, p. 27-47, doi: 10.1144/SP386.17.

Tobin, R.C., McClain, T., Lieber, R.B., Ozkan, A., Banfield, L.A., Marchand, A.M.E., and McRae, L.E., 2010, Reservoir quality modeling of tight-gas sands in Wamsutter field: Integration of diagenesis, petroleum systems, and production data: American Association of Petroleum Geologists Bulletin, v. 94, p. 1229-1266, doi: $\underline{10.1306 / 04211009140 .}$.

Tournier, F., Pagel, M., Portier, E., Wazir, I., and Fiet, N., 2010, Relationship between deep diagenetic quartz cementation and sedimentary facies in a late Ordovician glacial environment (Sbaa Basin, Algeria): Journal of Sedimentary Research, v. 80, p. 10681084, doi: $10.2110 /$ jsr.2010.094.

Turner, B.R., Makhlouf, I.M., and Armstrong, H.A., 2005, Late Ordovician (Ashgillian) glacial deposits in southern Jordan: Sedimentary Geology, v. 181, p. 73-91, doi: 10.1016/j.sedgeo.2005.08.004.

Van de Weerd, A.A., and Ware, P.L.G., 1994, A review of the East Algerian Sahara oil and gas province (Triassic, Ghadames and Illizi Basins): First Break, v. 12, p. 363-373, doi: $\underline{10.3997 / 1365-2397.1994023 .}$.

Vaslet, D., 1990, Upper Ordovician glacial deposits in Saudi Arabia: Episodes, v. 13, 147161.

Vavra, C.I., Kaldi, J.G., and Sneider, R.M., 1992, Geological applications of capillary pressure: A review: American Association of Petroleum Geologists Bulletin, v. 76, p. 840-850.

Walderhaug, O., 1994, Precipitation rates for quartz cement in sandstones determined by fluid-inclusion microthermometry and temperature-history modeling: Journal of Sedimentary Research, v. 64A, p. 324-333.

Walderhaug, O., 1996, Kinetic modeling of quartz cementation and porosity loss in deeply buried sandstone reservoirs: American Association of Petroleum Geologists Bulletin, v. 80, p. 731-745. 
1 Walderhaug, O., 2000, Modeling quartz cementation and porosity in Middle Jurassic Brent Group sandstones of the Kvitebjorn field, northern North Sea: American Association of Petroleum Geologists Bulletin, v. 84, p. 1325-1339, doi: 10.1306/A9673E96-173811D7-8645000102C1865D.

5 Wells, M., Hirst, P., Bouch, J., and Whear, E., and Clark, 2015, Deciphering multiple controls on reservoir quality and inhibition of quartz cement in a complex reservoir: Ordovician glacial sandstones, Illizi Basin, Algeria. Geological Society of London, v. 435, doi: 10.1144/SP435.6.

9 


\section{$1 \quad$ List of Figures and Tables}

2 Figure 1: Regional map showing the location of the Illizi Basin in Algeria and the study area.

$3 \quad$ TFT $=$ Tin Fouyé Tabankort.

4 Figure 2: (a) Stratigraphic column from the Cambrian to the lower Silurian source rocks in

5 the Illizi Basin. (b) Simplified gamma ray and schematic log showing the typical facies

6 associations within the Ordovician Unit IV. The syn-glacial sequence illustrated here

7 represents a single glacial cycle - erosion and subglacial facies overlain by a retrogradational

8 succession of glaciomarine fan deposits. Note the location of Units IV-3, IV-2, and IV-1,

9 which were the focus of this study.

Figure 3: 1D burial history model (Well A) for the study area in the Illizi Basin (modified from English et al., 2016c). Solid lines correspond to burial depth and dashed lines correspond to temperature.

Figure 4: (a) Simplified geological cross-section (A-A') showing the glacial valleys in outcrop in the Tassili N'Ajjer (modified from Deschamps et al., 2013). NNW-oriented glacial valleys can be in excess of $400 \mathrm{~m}$ deep with widths ranging from 2-10 km (Beuf et al., 1971; Galeazzi et al., 2010). (b) Simplified geological cross-section (B-B') from the study area showing a large incised glacial valley and the subdivision of the Unit IV in the subsurface. (c) Map showing the location of the section lines (map outline displayed in Figure 1).

Figure 5: (a) Schematic depositional model for the Ordovician syn-glacial succession. (b) Simplified sketch showing the internal geometry of the tidal sand ridges present at the top of the Ordovician in the Gara Nessaret area of the Tassili N'Ajjer (based on Beuf et al., 1971).

Figure 6: Core helium porosity and Klinkenberg permeability from the Upper Ordovician reservoir in the study area. All displayed core measurements were taken at 800 psi confining stress. (a) All data (417 samples) coded by stratigraphic unit. The best reservoir quality is typically found in the Unit IV-3 and occasionally in the Unit IV-1. (b) Subset of 70 samples selected for petrographic analysis to determine the primary controls on porosity and permeability preservation within this reservoir. Higher permeability $(>\sim 0.1 \mathrm{mD})$ and lower permeability $(<\sim 0.1 \mathrm{mD})$ samples will be herein referred to as Group A and Group B respectively. The kink in the dividing line between the two groups is due to a 'borderline' sample that was modelled with the Group A subset. 
1 Figure 7: Porosity and permeability of 69 Ordovician sandstone samples at varying levels of

2 net confining stress. For each core sample, five levels of net confining stress are shown: 800

3 psia (base case), 1900 psia, 3300 psia, 4500 psia, and 6000 psia. The high permeability Group

4 A samples are the least stress sensitive, while stress sensitivity increases in general in the

5 lower porosity and permeability samples.

6 Figure 8: (a) Pore throat radius distributions derived from mercury injection capillary 7 pressure tests (MICP). Port classification scheme is from Hartmann and Beaumont (1999).

8 (b) Strong positive correlation between modal pore throat radii and permeability. Within the 9 lower permeability Group B samples, the Unit IV-2 generally has the narrowest pore throat radii encountered in the study.

Figure 9: Saturation height above free water level (HAFWL) curves derived from MICP tests. Group A (black) and Group B (grey) curves are plotted according to (a) stratigraphic unit and (b) permeability. The Group B samples from the Unit IV-2 tend to be associated with the lowest permeability, highest capillary entry pressures, and the longest transition zones.

Figure 10: Porosity-permeability characteristics of the petrographic sample set coded by (a) mean grain size and (b) degree of sorting.

Figure 11: Grain size histograms for each of the Ordovician stratigraphic units and coded according to Group A (black) and Group B (grey).

Figure 12: (a) Preserved intergranular porosity in a clean fine grained sandstone in Unit IV-3 (Well H: 1961.97 m). Inset: (Well H: 1961.33 m) Discontinuous bitumen coats on a quartz faces. (b) Low permeability sandstone with high porosity due to poorly connected mouldic pores from the Unit IV-1 (Well F: 1970.75 m). (c) Stylolitic Unit IV-3 sandstone with evidence of remnant k-spar and detrital clay replaced by pyrite in places (Well A: 1918.97 m). (d) Poorly sorted Unit IV-3 with k-spar concentrated in the finer grained fraction. Note the sutured boundaries between quartz grains due to chemical compaction (Well C: 1897.13 $\mathrm{m})$. (e) Evidence of detrital clay coat on grain boundary preventing nucleation of quartz cement. Quartz cement was able to nucleate between gaps of the clay rims from adjacent grains (Well A: $1922.88 \mathrm{~m}$ ). (f) Coarse grained sandstone with polycrystalline quartz (Qp: 6\%). Kaolinite is observed to be oil-stained (Well G: $1943.71 \mathrm{~m}$ ). 
1 Figure 13: Sandstone classification based on detrital quartz (Q), feldspar (F) and rock

2 fragment (R) contents (Folk, 1974). The sample set is focussed in the apex of the QFR

3 diagram and most of the samples are quartzarenites. The samples with increased feldspar

4 content are typically silt or very fine grained samples contained in the Units IV-2 and IV-1.

5 The depositional feldspar content of the sandstones was estimated in the diagenetic models

6 by assuming a closed chemical system and that the aluminium (Al) content in the authigenic

7 illite and kaolinite was derived from the initial feldspar content. Reconstructed compositions

8 show that some Group B samples were originally in the arkose-subarkose category. Group A

9 and $\mathrm{B}$ were likely more distinct at deposition compared to their current framework grain compositions.

Figure 14: Summary porosity-permeability characteristics in the petrographic sample set coded according to: (a) presence or absence of original detrital feldspar, (b) presence or absence of a pore-filling illite cement phase, and (c) dominance of visible primary intergranular porosity versus secondary mouldic porosity. Original detrital feldspar and illite cements are generally absent from the higher permeability Group A sandstones dominated by primary intergranular porosity. Conversely, original detrital feldspar and illite cementation are more common in the fine-grained Group B sandstones, which are dominated by secondary mouldic porosity. Pore-filling illite is completely absent from the higher permeability $(>0.1 \mathrm{mD})$ Unit IV-3 sandstones.

Figure 15: ESEM micrographs: (a) Point to point grain contacts with connected intergranular porosity are well-preserved in the permeable Group A samples (Well A: $1918 \mathrm{~m}$ ). (b) In lower permeability Group B samples, extensive authigenic quartz cementation has significantly reduced the reservoir quality (Well A: $1923.5 \mathrm{~m}$ ). (c) Pore-lining platey illite (I1) of possible detrital origin (Well A: 1914 m). (d) Pore-filling fibrous illite (I2) occupying mouldic pores (Well A: $1934.05 \mathrm{~m}$ ).

Figure 16: Comparison between medium and fine grained sandstones in the north and south of the study area. Note the higher quartz cement volumes present in the samples from the south (Well G). Improved reservoir quality is observed in medium grained versus fine grained samples.

Figure 17: Touchstone calibration results using a single set of optimized model parameters.

Tolerance limits for porosity, quartz cement, and intergranular volume are set at \pm 4 vol.\%. 
1 Figure 18: Paragenetic sequence of the Group A and B facies. Representative samples were

2 run with 'north' and 'south' burial histories to capture the range in diagenetic evolution. The

3 size of the quartz cement, compaction, illite, kaolinite, and K-feldspar/lithic dissolution

4 shading is scaled according to the volumetric rates of change. The size of the barite,

5 carbonates, $\mathrm{Fe} / \mathrm{Ti}$ oxides, pyrite shadings are relatively exaggerated compared to the others to

6 make them easier to see. The formation of kaolinite and K-feldspar/lithic dissolution are

7 directly linked by $\mathrm{Al}$ mass balance and therefore genetically linked. Constraints on timing of

8 cement phases from fluid inclusion data is indicated for quartz and barite relative to the

9 temperature history of Well A and G. Onset of hydrocarbon expulsion began in the Carboniferous with renewed expulsion occurring in the Cretaceous-Eocene (English et al., 2016c).

Figure 19: Touchstone prediction distributions using stochastic simulations for Group A. Note the good agreement between the stochastic predictions for the north and south regions, and the measured sample data. Group A calibration samples all have permeability in excess of $0.1 \mathrm{mD}$ and may not fully represent the low-end of the reservoir quality in the southern area as predicted by the model.

Figure 20: Evolution of porosity and permeability through time derived from prediction distributions in Touchstone. Depositional mean porosity begins at $\sim 35 \%$ but is eventually reduced to $9.2 \%$ (and $131 \mathrm{mD}$ geometric mean permeability) in the north of the field and $4.1 \%$ in the south of the field (and $1.1 \mathrm{mD}$ geometric mean permeability), though the statistical P10 and P90 ranges account for variability in the original grain size, texture and composition.

Figure 21: Burial depth and predicted mean total porosity and geometric mean permeability maps through time for Group A facies. 286 Ma represents the onset of Hercynian exhumation at the end of the main hydrocarbon generation phase. $124 \mathrm{Ma}$ is an intermediate step in the evolution. The present-day maps indicate better reservoir quality in the north due to less burial and lower paleotemperatures. Note the discordance between present-day burial depth and predicted porosity and permeability. Ranges from the mean are described by P90 and P10 curves in Figure 20 and will depend on the original depositional grain size, texture and composition. Black circles are locations of 1-D models based on wells in the study area.

Table 1: Rock property summary of Upper Ordovician sandstones 
1 Table 2: Petrographic summary of Upper Ordovician sandstones

2 Table 3: Touchstone model parameters (Group A facies) 
ACCEPTED MANUSCRIPT

TABLE 1: ROCK PROPERTY SUMMARY OF UPPER ORDOVICIAN SANDSTONES

\begin{tabular}{|cc|c|c|c|c|}
\hline & & $\begin{array}{c}\text { GROUP A } \\
\text { (high k)* }\end{array}$ & $\begin{array}{c}\text { GROUP B } \\
\text { (Unit IV-3) }\end{array}$ & $\begin{array}{c}\text { GROUP B } \\
\text { (Unit IV-2) }\end{array}$ \\
\hline \hline (Unit IV-1)
\end{tabular}

"Group A includes mainly Unit IV-3 samples, but also some Unit IV-1 (see Fig. 6A).

** Includes 6 additional samples not included in main text and Figures 7 and 8 as only routine porosity and permeability measurements were available.

*** 1 anomalous poorly sorted Unit IV-3 sample (Fig. 12D) with a capillary entry pressure of 1717 psia and a modal pore throat radius of $0.02 \mu \mathrm{m}$ has been excluded from these statistics. 
TABLE 2: PETROGRAPHIC SUMMARY OF UPPER ORDOVICIAN SANDSTONES

\begin{tabular}{|c|c|c|c|}
\hline & & $\begin{array}{c}\text { GROUP A } \\
(k>0.1 \mathrm{mD})\end{array}$ & $\begin{array}{c}\text { GROUP B } \\
(k<0.1 \mathrm{mD})\end{array}$ \\
\hline \multicolumn{2}{|c|}{ Number of Samples } & 25 & 45 \\
\hline \multirow{6}{*}{$\begin{array}{l}\text { Core Data } \\
\text { (at } 800 \text { psia) }\end{array}$} & Helium & $4.7-11.4 \%$ & $1.3-11.8 \%$ \\
\hline & Porosity & (ave. $7.0 \pm 1.9 \%$ ) & (ave. $4.8 \pm 2.4 \%$ ) \\
\hline & Klinkenberg & $0.10-377.89 \mathrm{mD}$ & $0.0005-0.0496 \mathrm{mD}$ \\
\hline & Permeability & (ave. $60.21 \mathrm{mD}$; geomean $9.58 \mathrm{mD}$ ) & (ave. $0.0124 \mathrm{mD}$; geomean $0.0073 \mathrm{mD}$ ) \\
\hline & Grain & $2.63-2.67 \mathrm{~g} / \mathrm{cc}$ & $2.63-2.79 \mathrm{~g} / \mathrm{cc}$ \\
\hline & Density & (ave. $2.65 \pm 0.01 \mathrm{~g} / \mathrm{cc}$ ) & (ave. $2.65 \pm 0.02 \mathrm{~g} / \mathrm{cc}$ ) \\
\hline \multirow{3}{*}{ Texture } & $\begin{array}{c}\text { Grain Size } \\
\text { (Mean Grain Size) }\end{array}$ & $\begin{array}{c}\text { fine sand to coarse sand } \\
(0.14-0.51 \mu \mathrm{m} ; \text { ave. } 0.25 \pm 0.09 \mu \mathrm{m})\end{array}$ & $\begin{array}{l}\text { very fine sand to medium sand } \\
(0.06-0.31 \mu \mathrm{m} ; \text { ave. } 0.18 \pm 0.07 \mu \mathrm{m})\end{array}$ \\
\hline & $\begin{array}{c}\text { Sorting } \\
\text { (Trask Coefficient) }\end{array}$ & $\begin{array}{c}\text { poor to moderately-well } \\
(1.40-2.20 \text {; ave. } 1.70 \pm 0.21)\end{array}$ & $\begin{array}{c}\text { poor to well } \\
(1.37-2.51 ; \text { ave. } 1.71 \pm 0.25)\end{array}$ \\
\hline & $\begin{array}{c}\text { Compaction } \\
\text { (Intergranular Volume) }\end{array}$ & $\begin{array}{c}\text { mild to severe } \\
\text { (15- } 28 \% \text {; ave. } 24 \pm 3 \%)\end{array}$ & $\begin{array}{c}\text { mild to severe } \\
\text { (16- } 42 \% \text {; ave. } 26 \pm 6 \%)\end{array}$ \\
\hline \multirow{6}{*}{$\begin{array}{l}\text { (Preserved) } \\
\text { Detrital } \\
\text { Composition }\end{array}$} & (م) ב-Ouart & $97.2-100 \%$ & $90.3-100 \%$ \\
\hline & QuditL (U) & (ave. $99.6 \pm 0.7 \%$ ) & (ave. $98.6 \pm 2.0 \%$ ) \\
\hline & Feldspar (F) & $0.5 \%$ (1 sample) & 0.4 - $9.2 \%$ (11 samples) \\
\hline & & & (ave. $2.8 \pm 3.2 \%$ ) \\
\hline & Rock Fragments (RF) & $\begin{array}{c}0.4-2.8 \% \text { (9 samples) } \\
\text { (ave. } 1.1 \pm 0.8 \% \text { ) }\end{array}$ & $\begin{array}{c}0.4-2.3 \% \text { (34 samples) } \\
\text { (ave. } 0.9 \pm 0.5 \% \text { ) }\end{array}$ \\
\hline & Primary Matrix Clay & $\begin{array}{c}0.7-4.0 \% \text { (18 samples) } \\
\text { (ave. } 1.7 \pm 0.9 \% \text { ) }\end{array}$ & $\begin{array}{c}0.3-14.7 \% \text { (18 samples) } \\
\text { (ave. } 2.1 \pm 3.4 \% \text { ) }\end{array}$ \\
\hline Grain Coating & Mean Grain Coat Area & $\begin{array}{c}15-42 \% \\
\text { (ave. } 30 \pm 8 \% \text { ) }\end{array}$ & $\begin{array}{c}8-79 \% \\
\text { (ave. } 37 \pm 16 \% \text { ) }\end{array}$ \\
\hline \multirow{7}{*}{$\begin{array}{l}\text { Authigenic } \\
\text { Mineralogy }\end{array}$} & Quartz & $\begin{array}{c}8.7-22.3 \% \\
\text { (ave. } 14.2 \pm 3.9 \% \text { ) }\end{array}$ & $\begin{array}{c}5.3-31.3 \% \\
\text { (ave. } 20.1 \pm 5.3 \% \text { ) }\end{array}$ \\
\hline & Mlite & 0.7 - $3.0 \%$ (5 samples) & $0.3-12.3 \%$ (41 samples) \\
\hline & minte & (ave. $1.3 \pm 1.0 \%$ ) & (ave. $3.1 \pm 2.8 \%$ ) \\
\hline & Kaolinite & $0.3-1.3 \%$ ( 2 samples) & $0.3-7.3 \%$ (7 samples) \\
\hline & kaommite & (ave. $0.8 \pm 0.7 \%$ ) & (ave. $1.8 \pm 2.5 \%$ ) \\
\hline & Bitumen / & $0.3-2.3 \%$ (16 samples) & $0.3-4.3 \%$ (15 samples) \\
\hline & Heavy Hydrocarbon & (ave. $0.8 \pm 0.7 \%$ ) & (ave. $1.4 \pm 1.3 \%$ ) \\
\hline \multirow{3}{*}{$\begin{array}{l}\text { Visible } \\
\text { Porosity }\end{array}$} & Intergranular & 4.6 - 11.3\% (25 samples) & $0.3-3.0 \%$ (30 samples) \\
\hline & & (ave. $6.9 \pm 1.9 \%$ ) & (ave. $1.2 \pm 0.7 \%$ ) \\
\hline & Mouldic & 0.3 - $5.7 \%$ (12 samples) & $0.3-7.0 \%$ (41 samples) \\
\hline
\end{tabular}




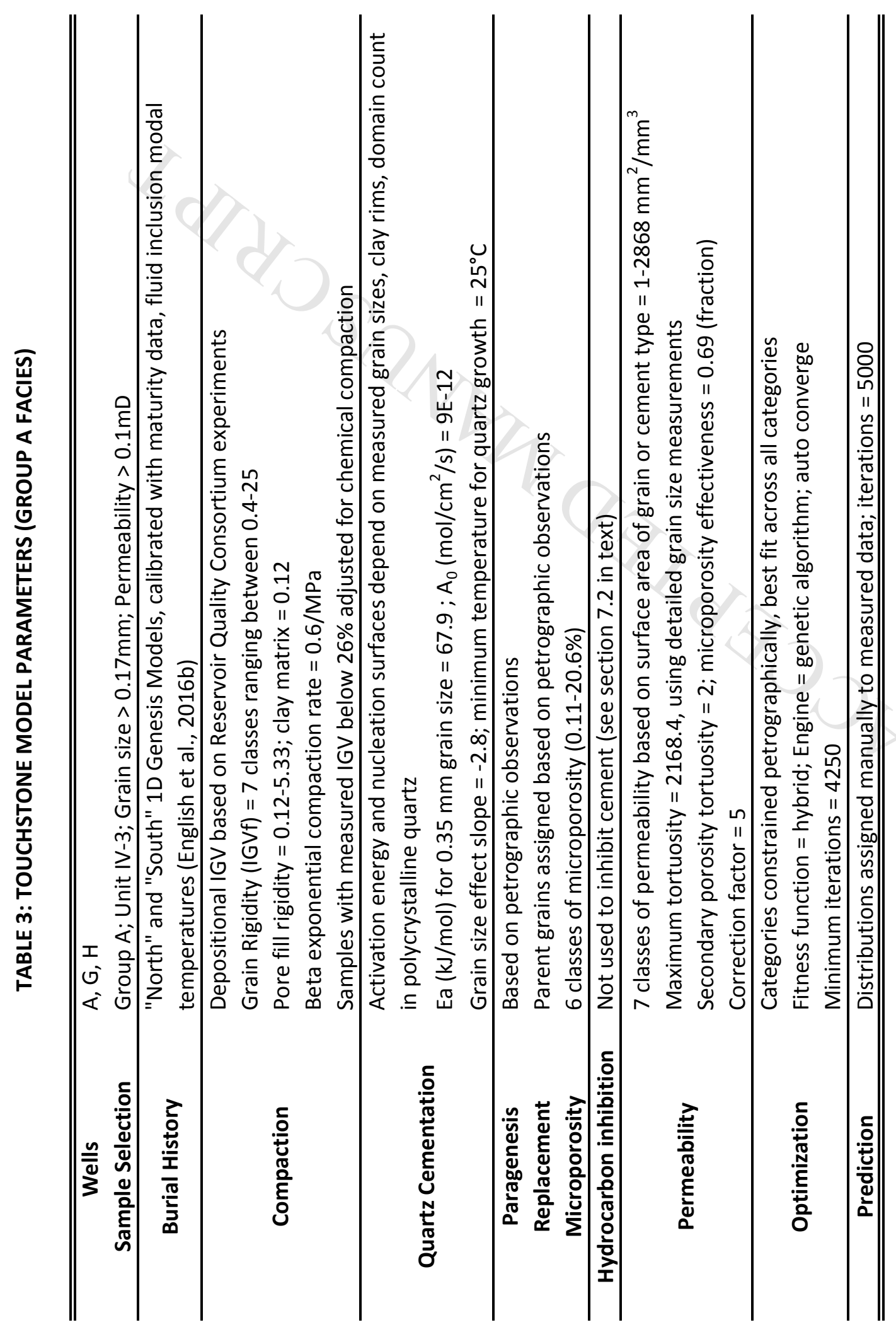




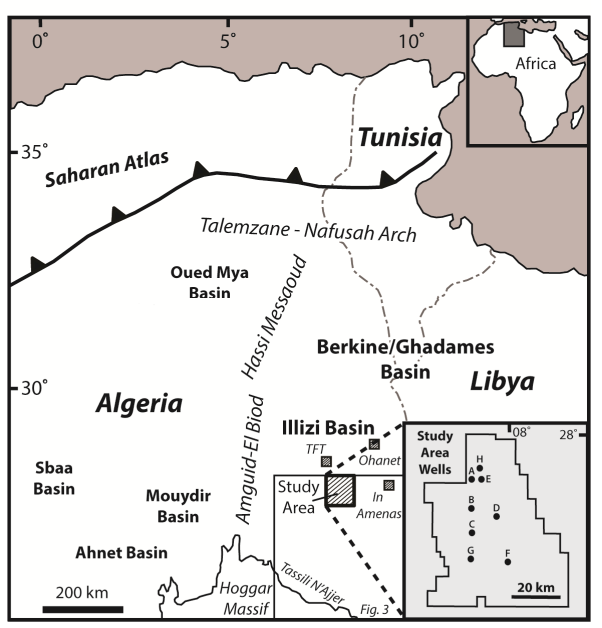




\section{ACCEPTED MANUSCRIPT}

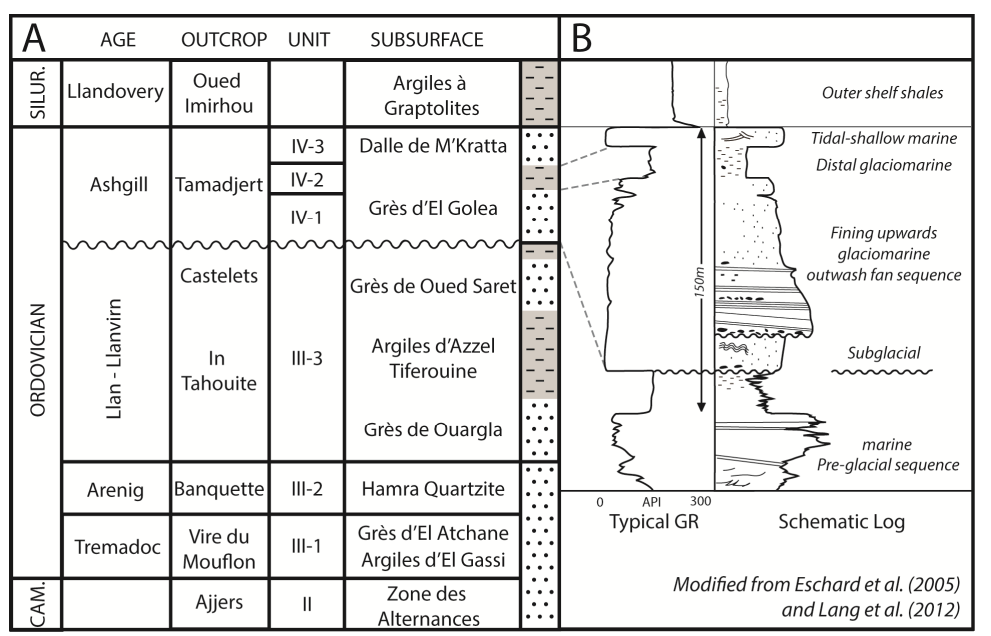




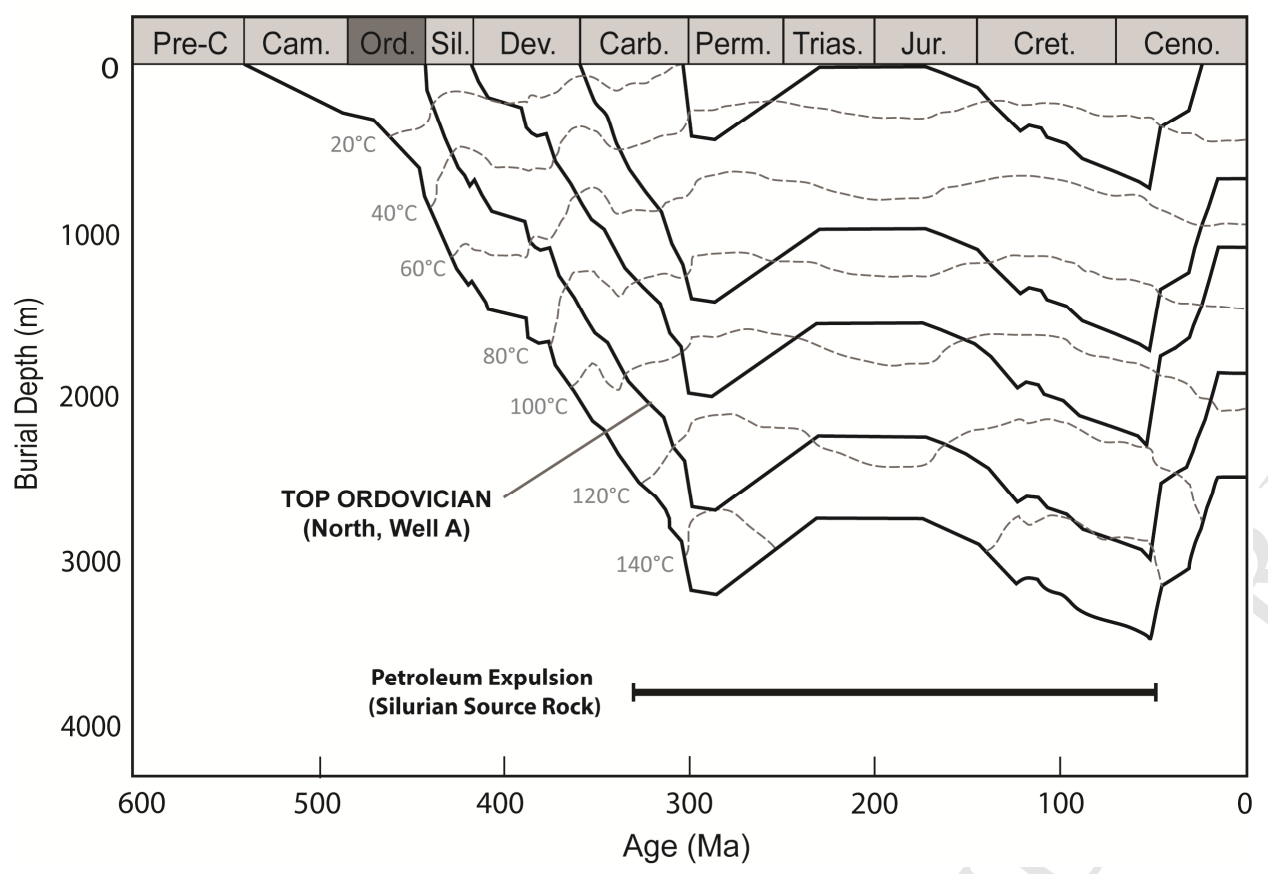




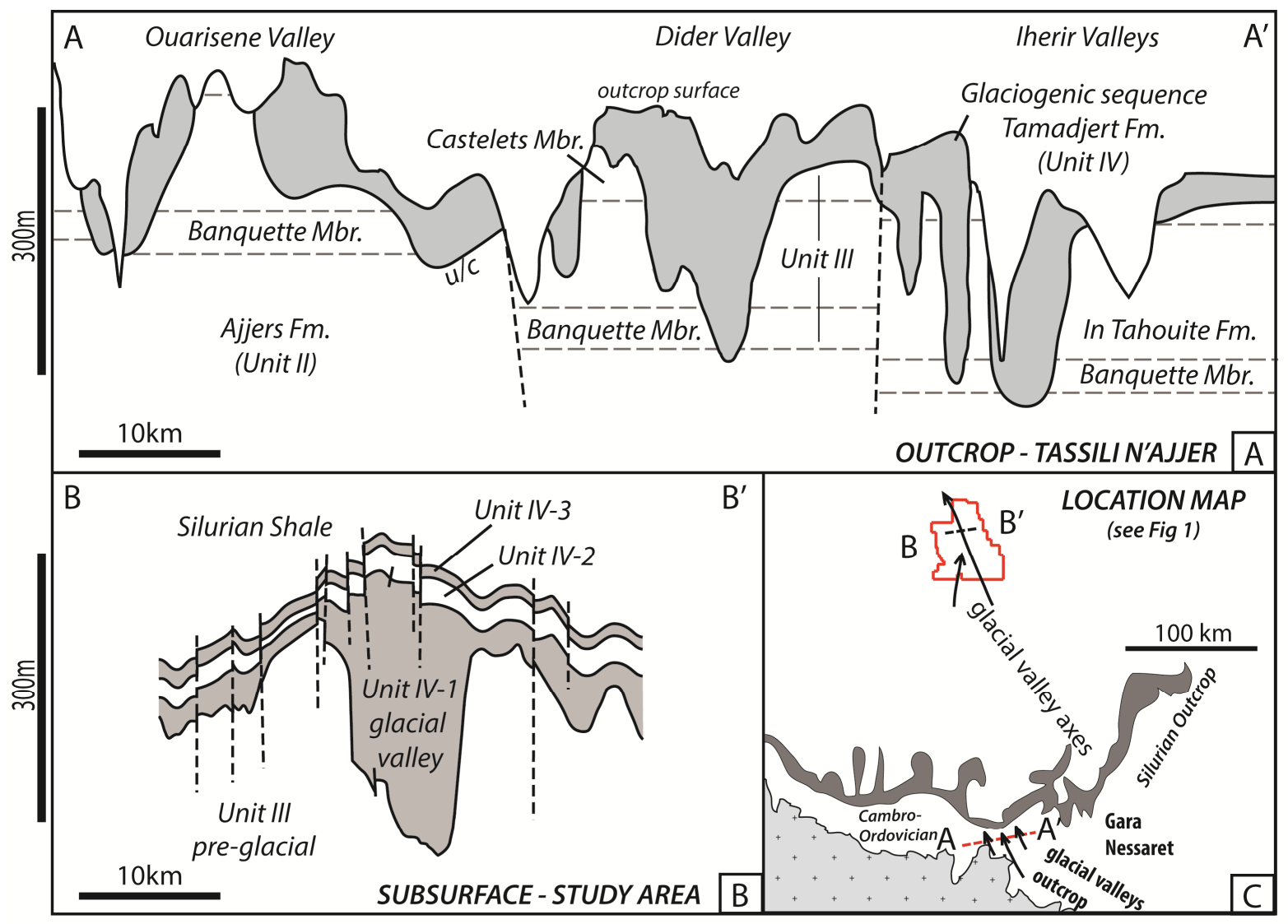




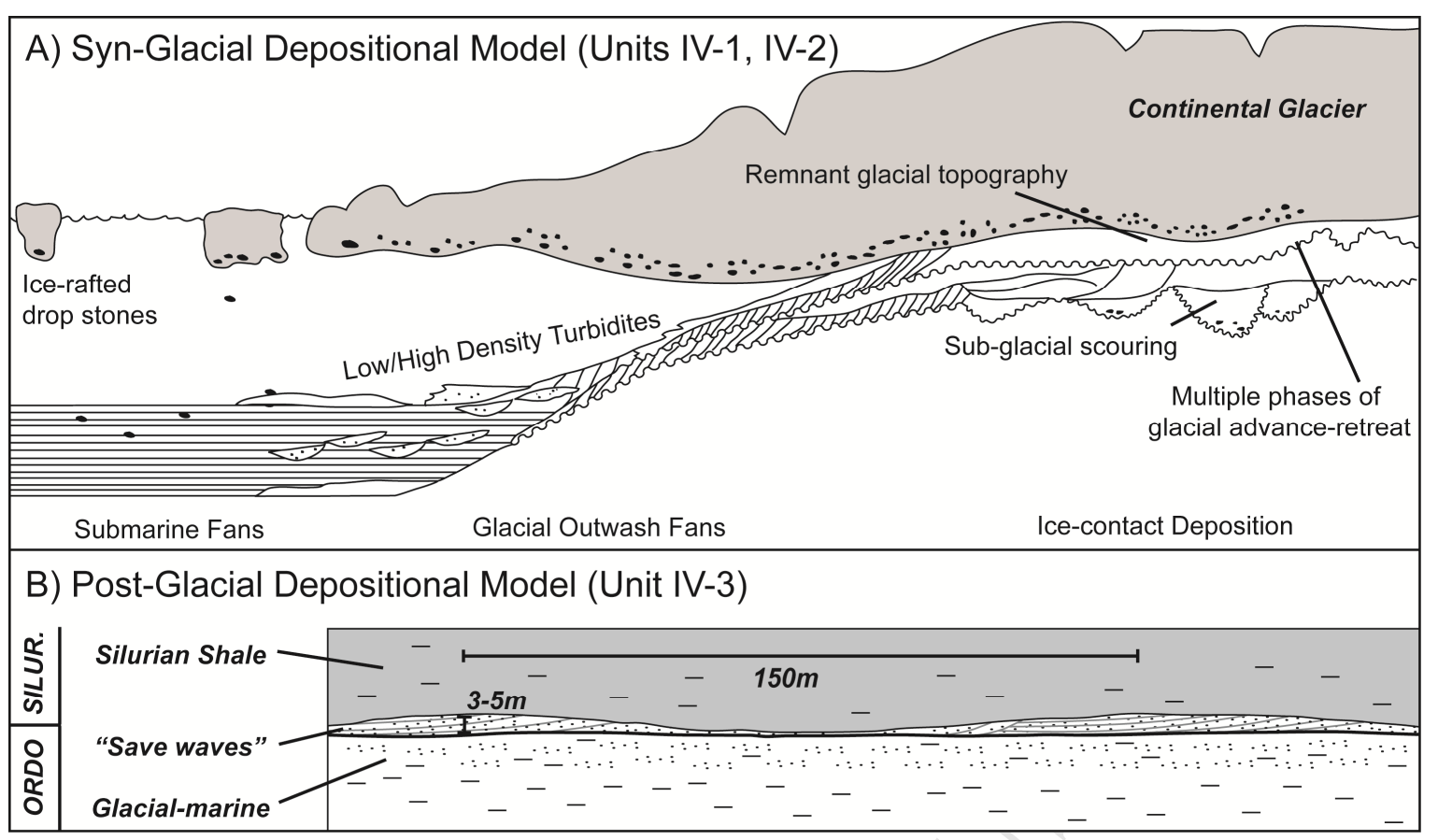



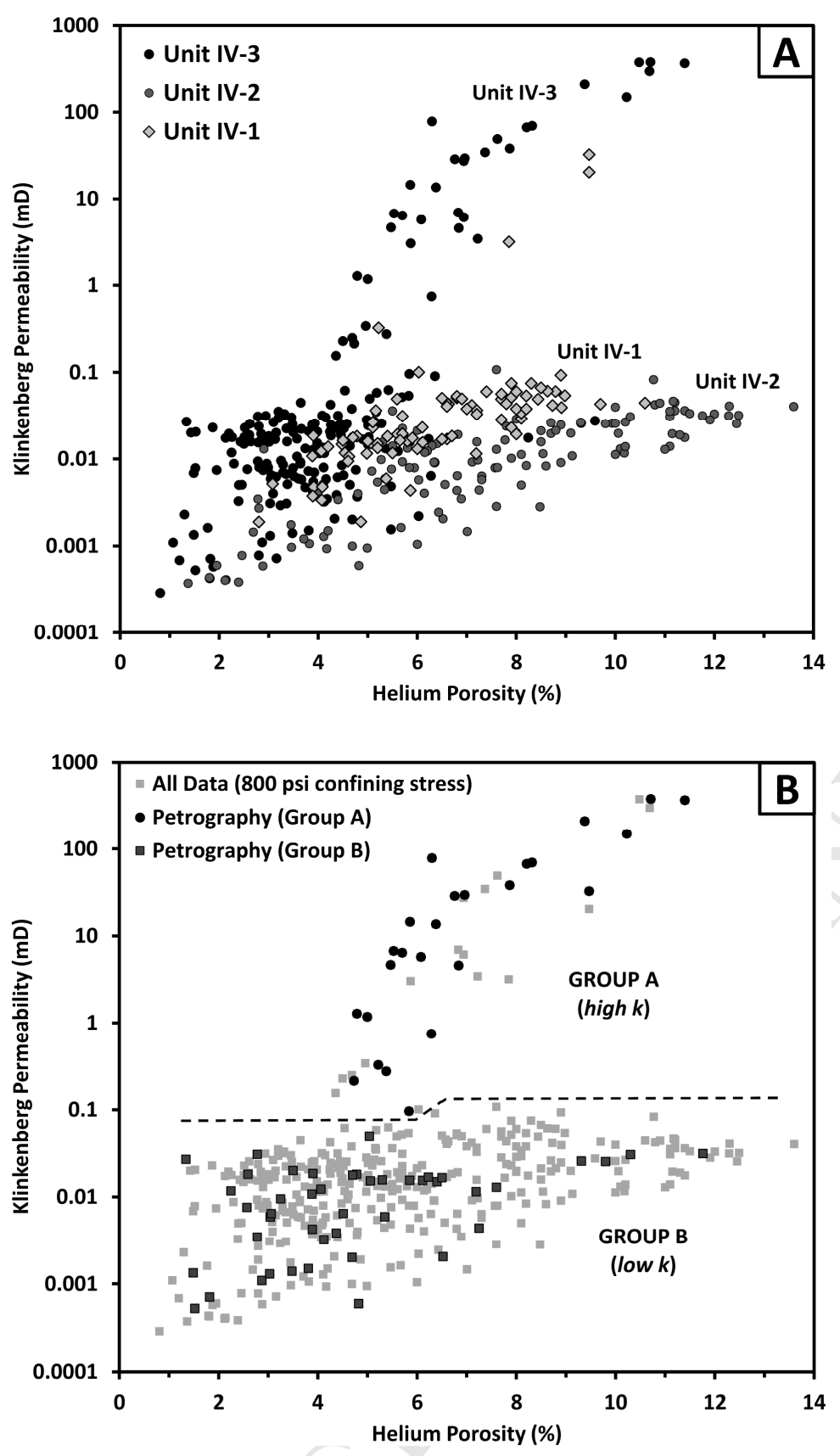


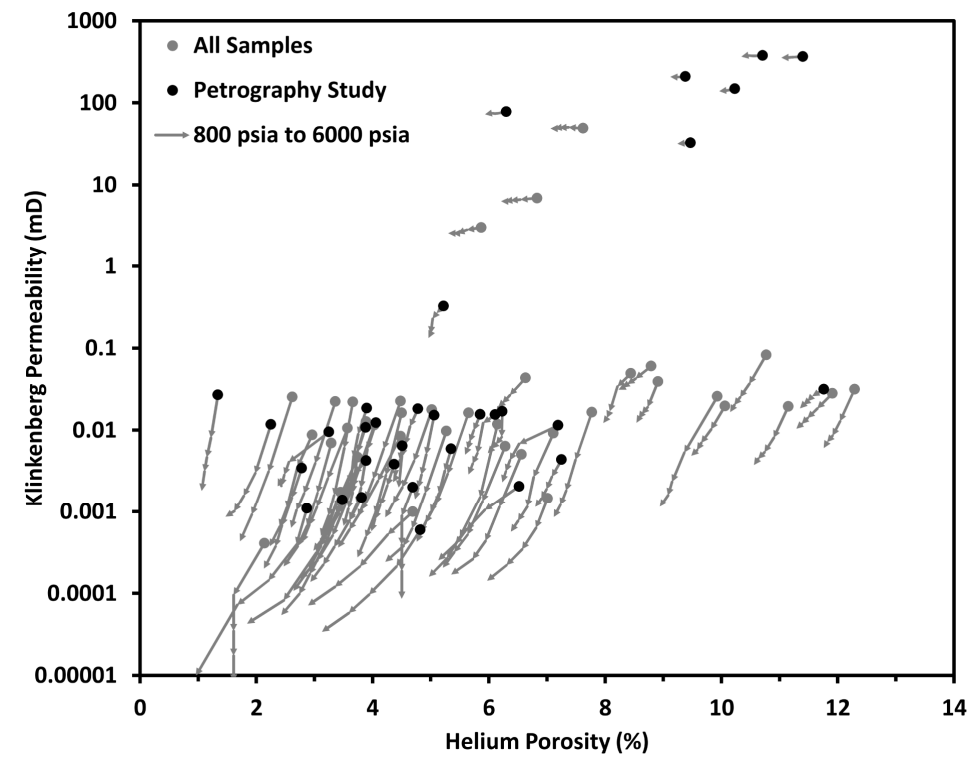



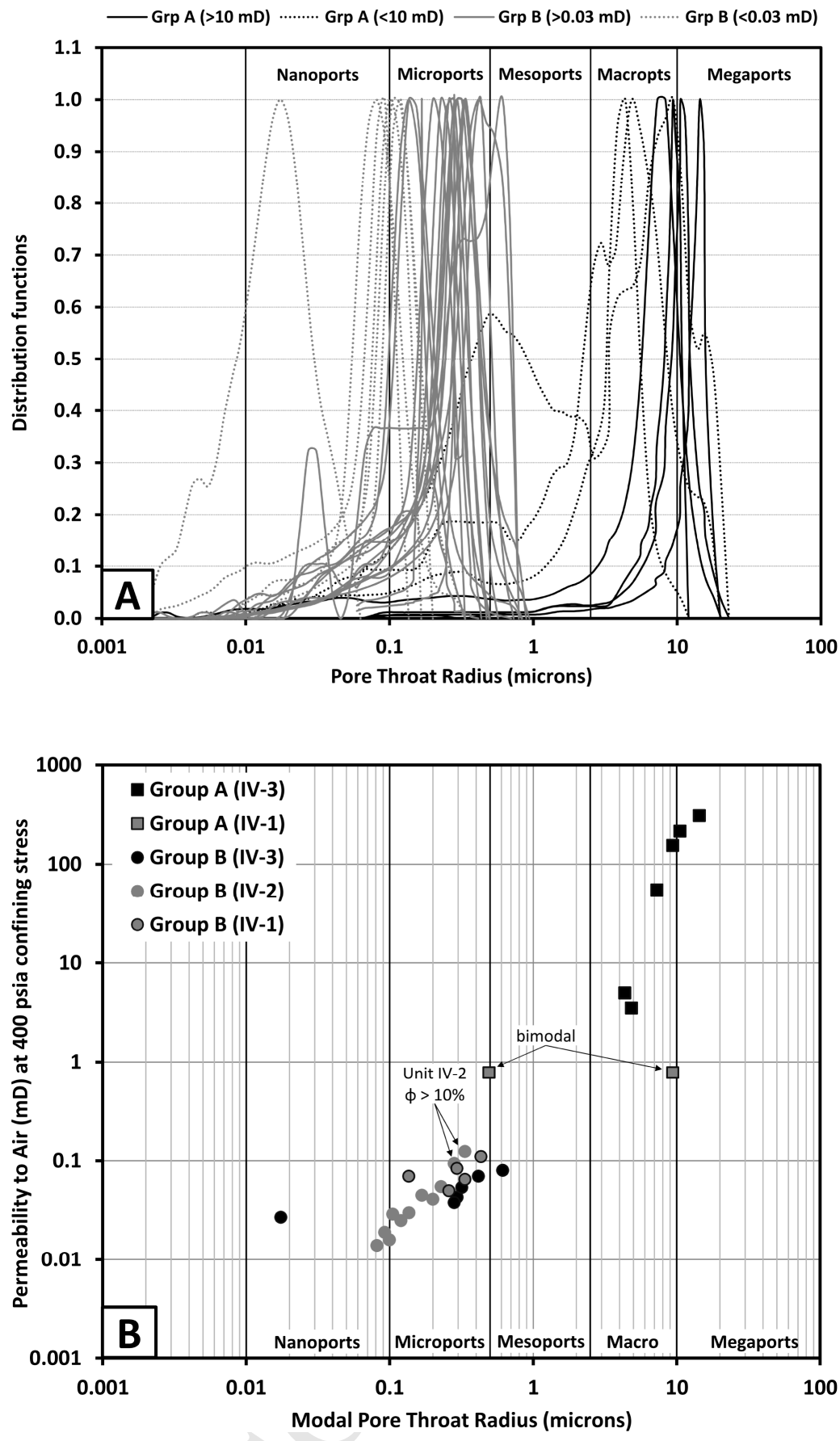

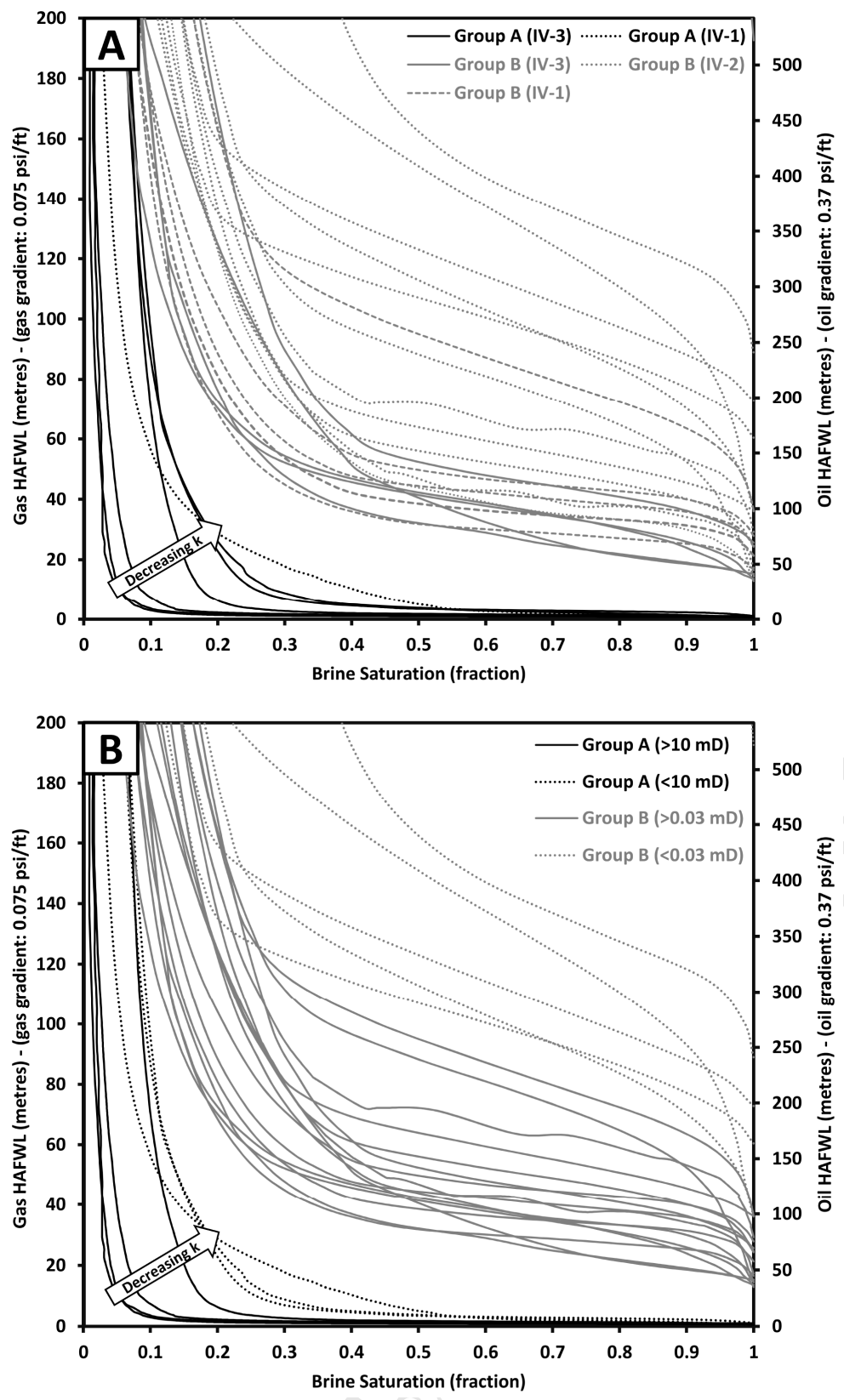

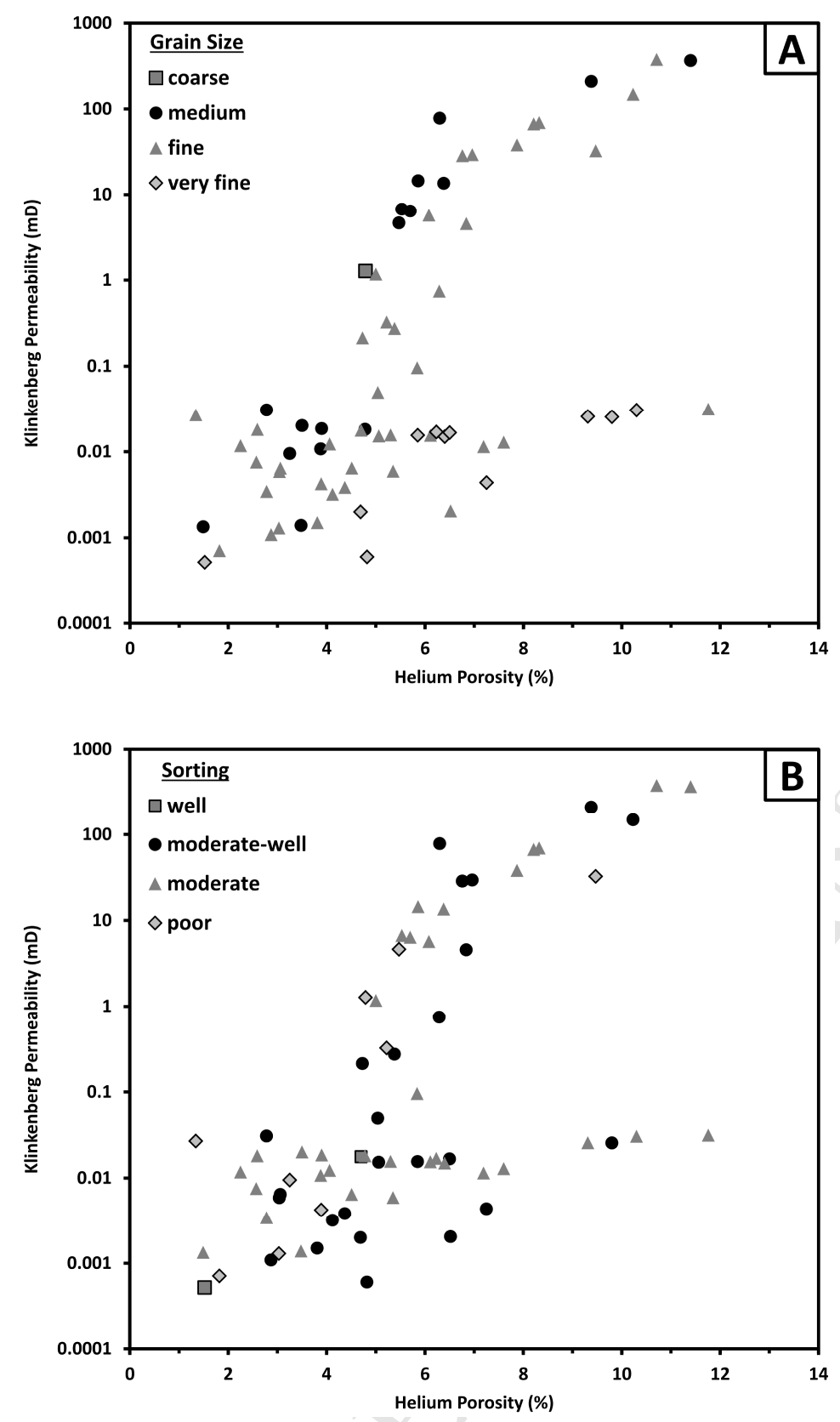


\section{ACCEPTED MANUSCRIPT}
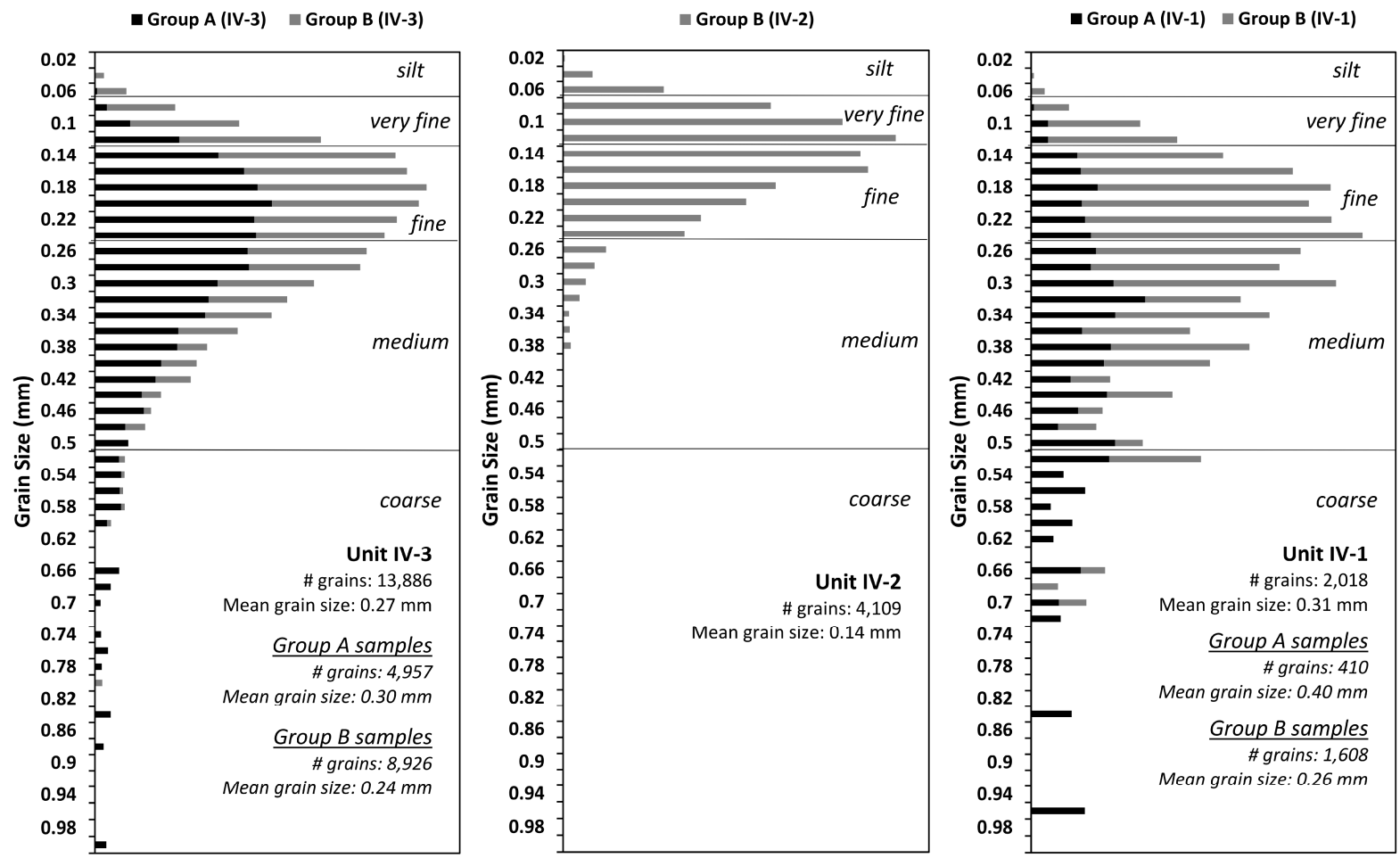

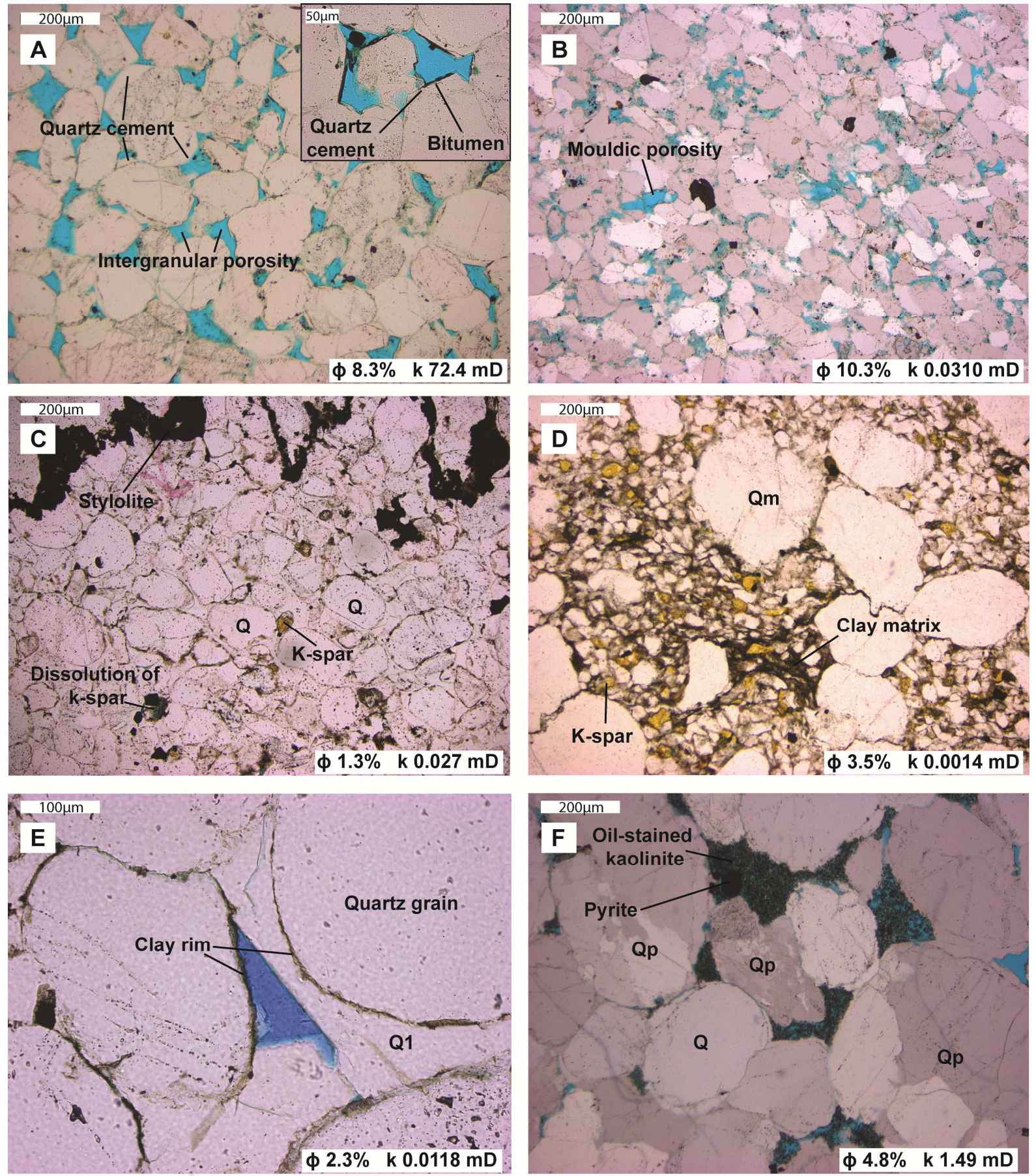
Present-day

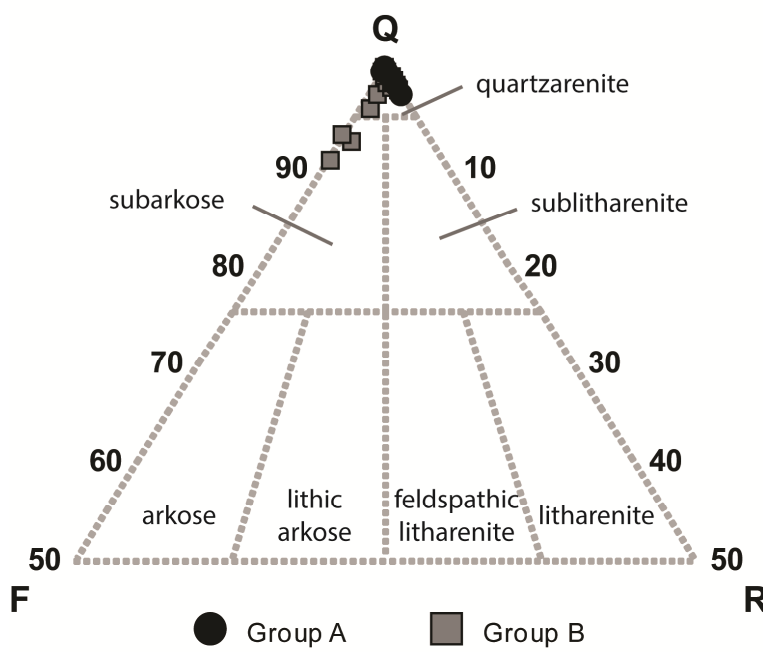

Reconstructed Depositional

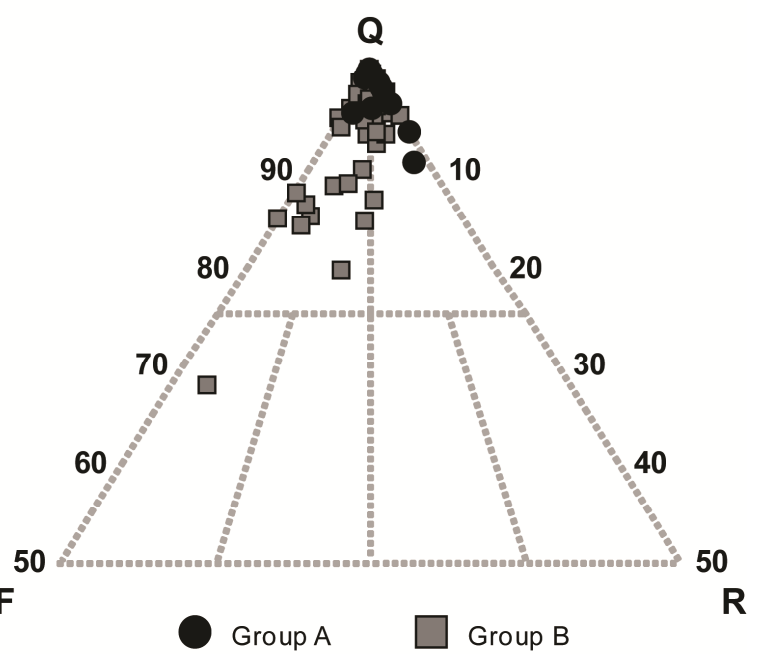



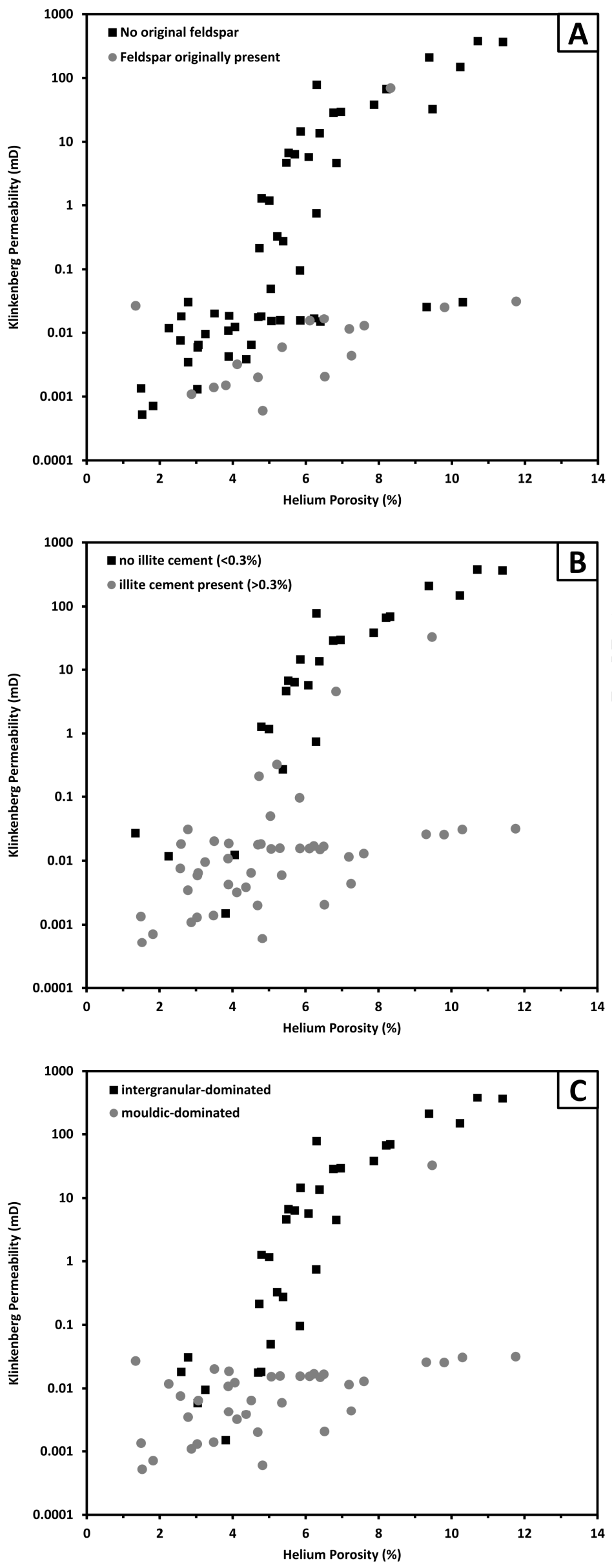

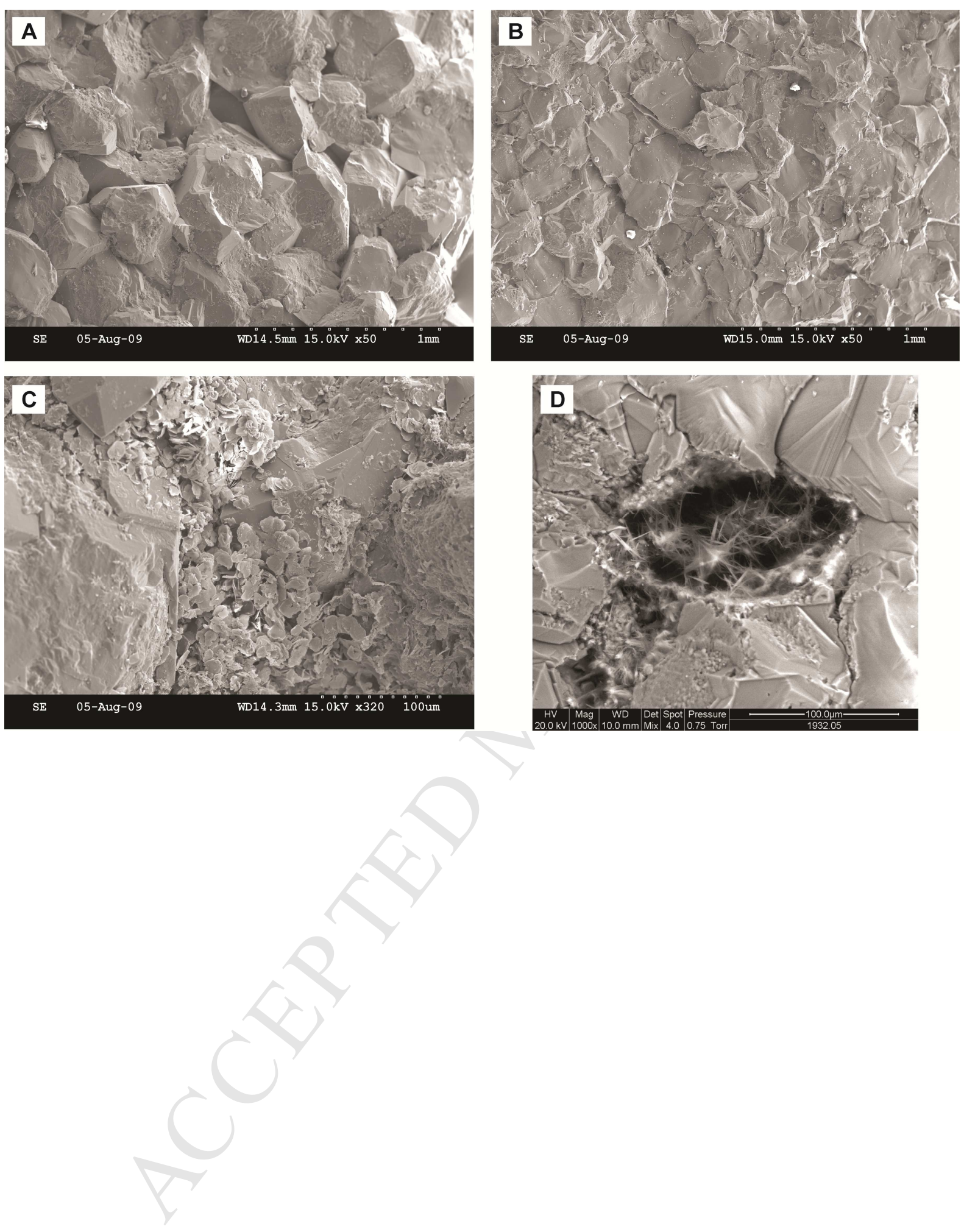
NORTH

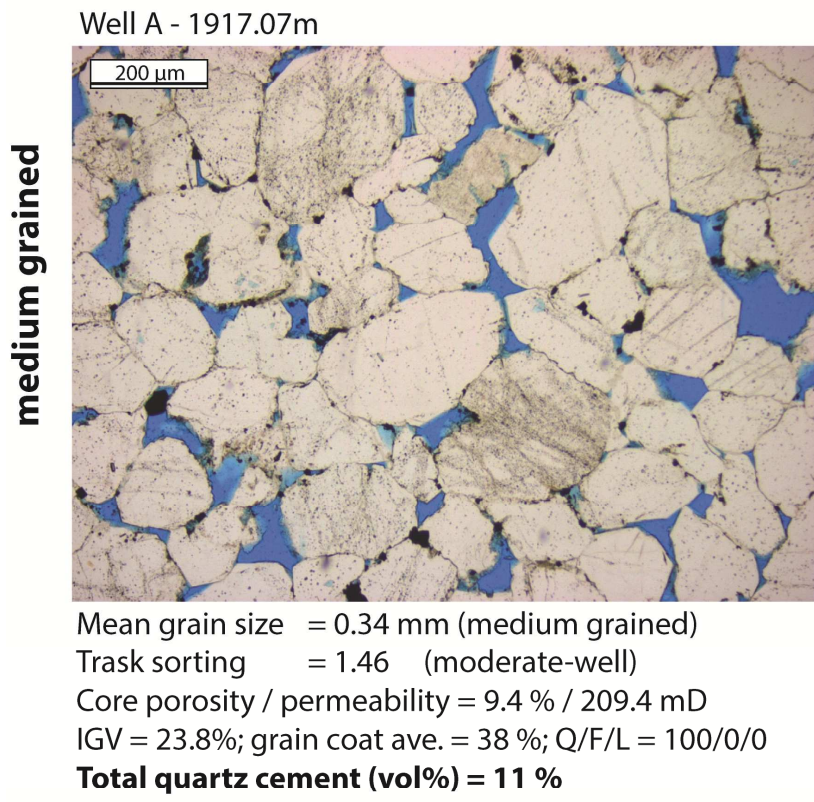

\section{SOUTH}

Well G - 1943.53m

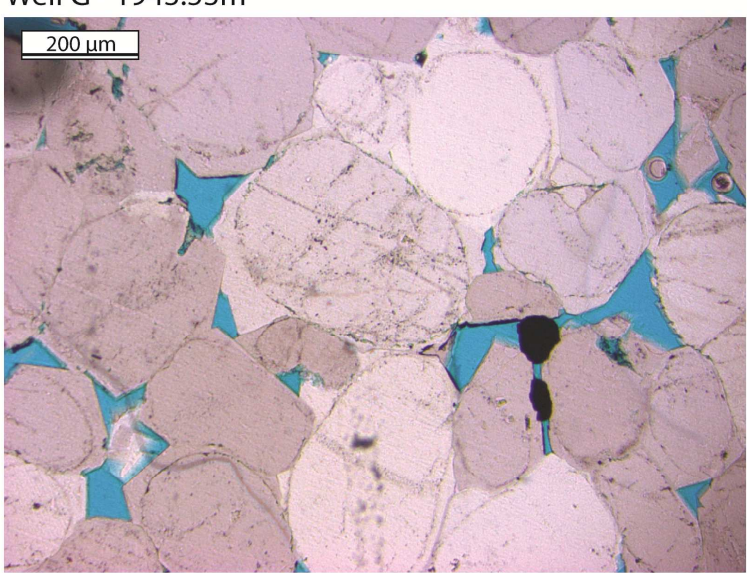

Mean grain size $=0.40 \mathrm{~mm}$ (medium grained) Trask sorting $=1.89$ (moderate) Core porosity / permeability $=5.7 \% / 6.4 \mathrm{mD}$ IGV = 27.9\%; grain coat ave. $=40 \%$; $/ F / L=100 / 0 / 0$ Total quartz cement $(\mathrm{vol} \%)=\mathbf{2 2} \%$

Well G - 1942.28m

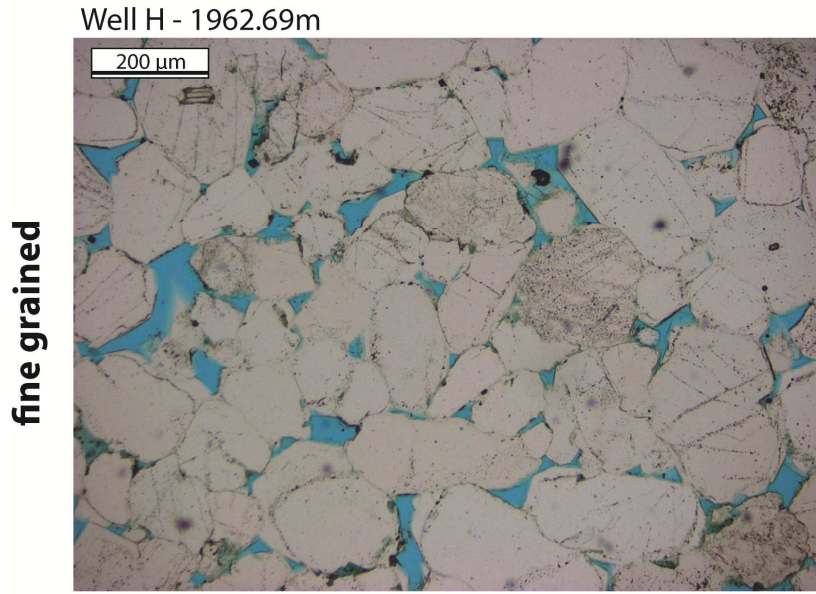

Mean grain size $=0.22 \mathrm{~mm}$ (fine grained)

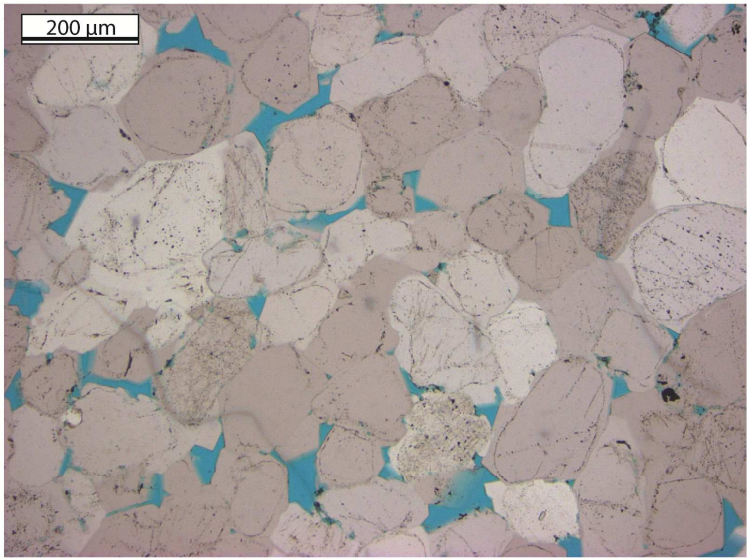

Mean grain size $=0.22 \mathrm{~mm}$ (fine grained)

Trask sorting $=1.54$ (moderate-well)

Core porosity / permeability $=4.7 \% / 0.2 \mathrm{mD}$

IGV = 26.6\%; grain coat ave. $=33 \% ; \mathrm{Q} / \mathrm{F} / \mathrm{L}=100 / 0 / 0$

Total quartz cement $($ vol $\%)=\mathbf{2 2} \%$

IGV = 23.3\%; grain coat ave. $=33 \% ; \mathrm{Q} / \mathrm{F} / \mathrm{L}=100 / 0 / 0$

Total quartz cement $(\mathrm{vol} \%)=10 \%$ 

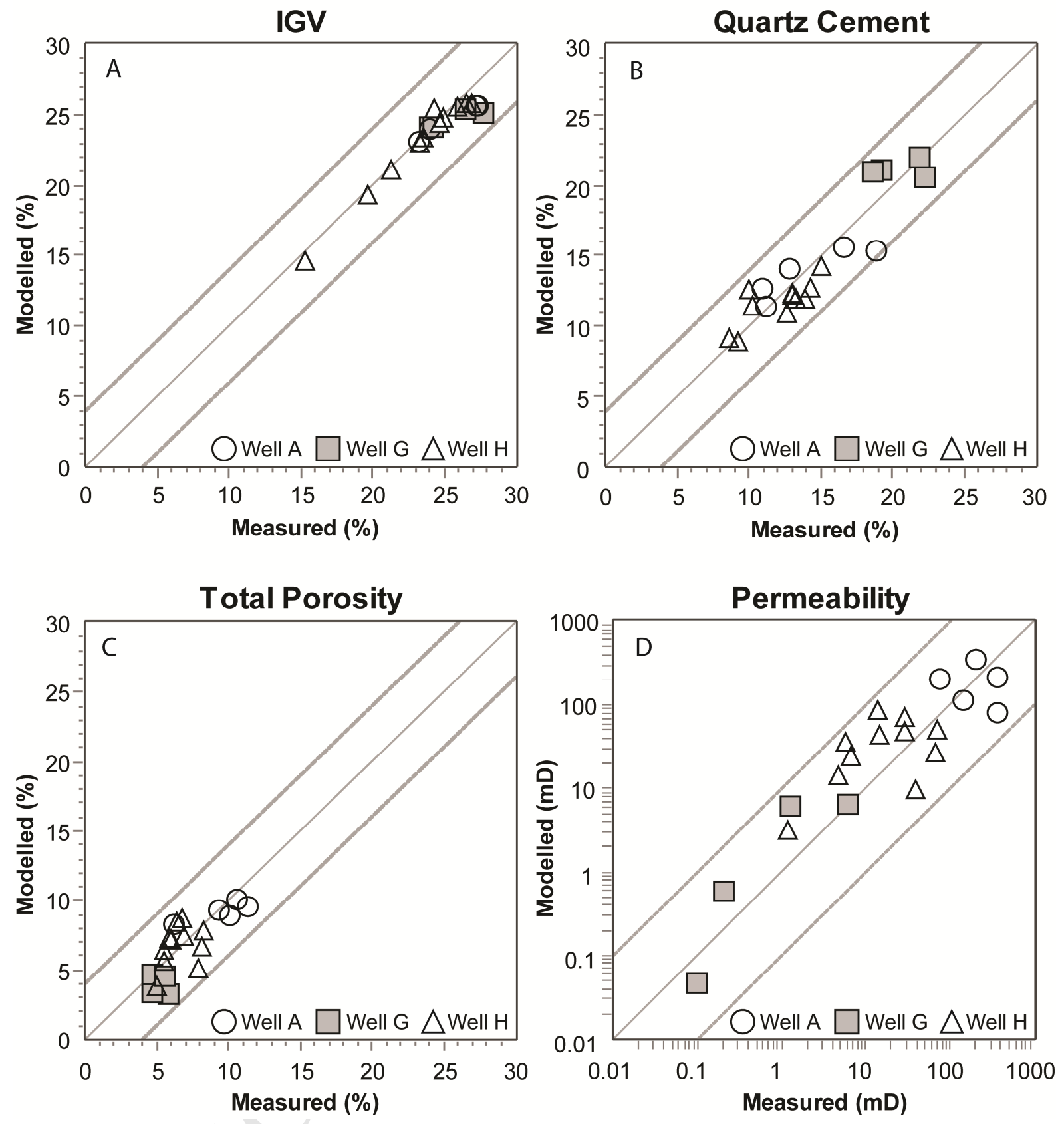


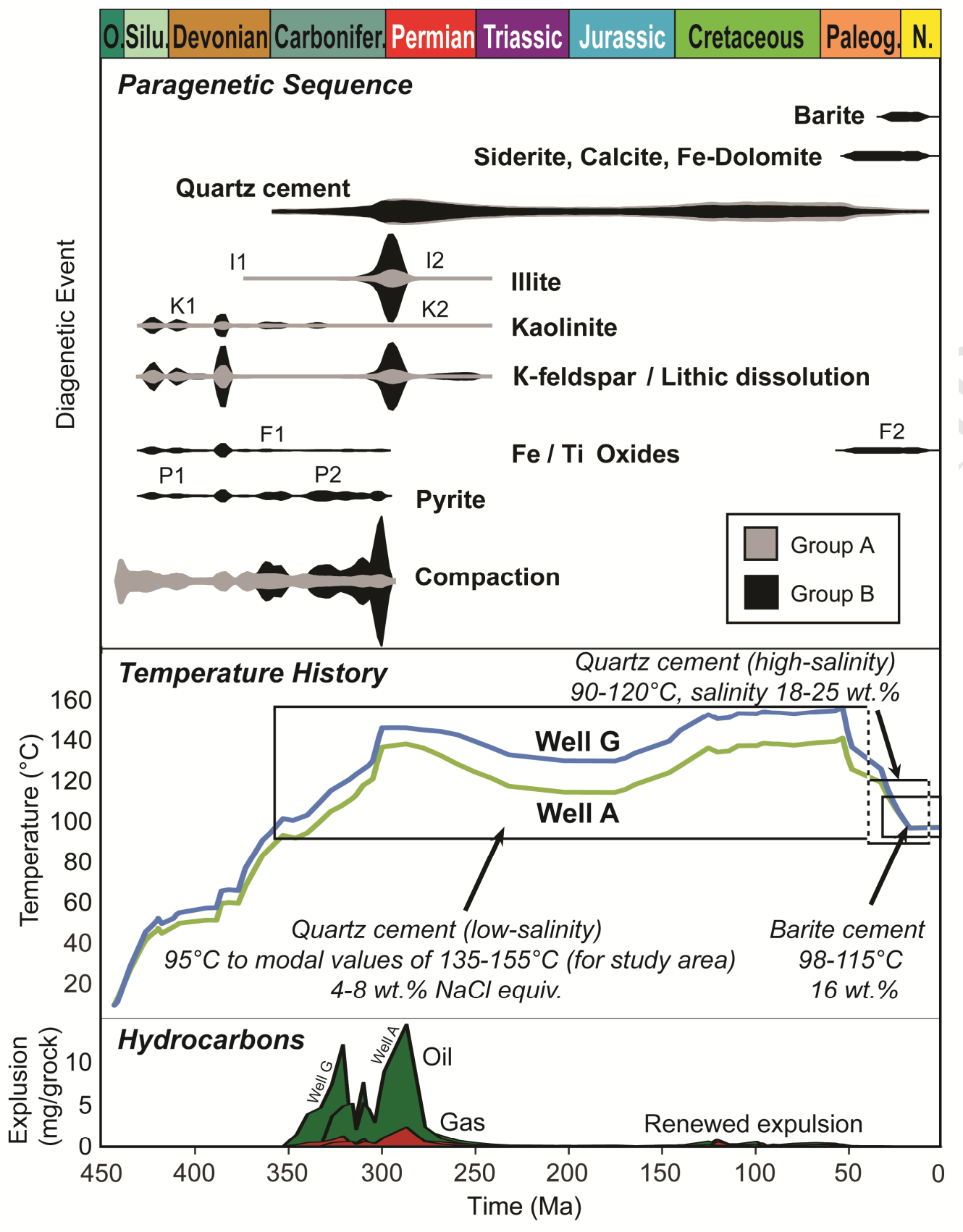




\section{A NORTH (Maximum Temperature $140^{\circ} \mathrm{C}$ )}
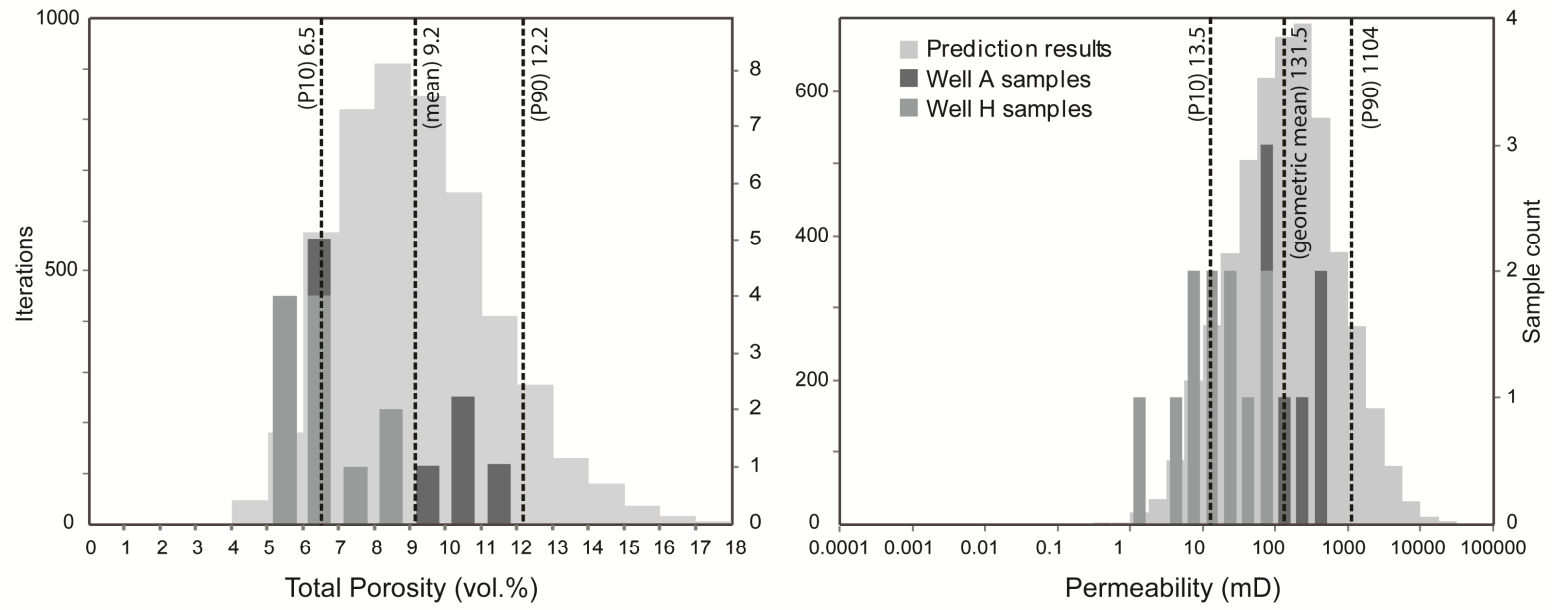

\section{B SOUTH (Maximum Temperature $156^{\circ} \mathrm{C}$ )}
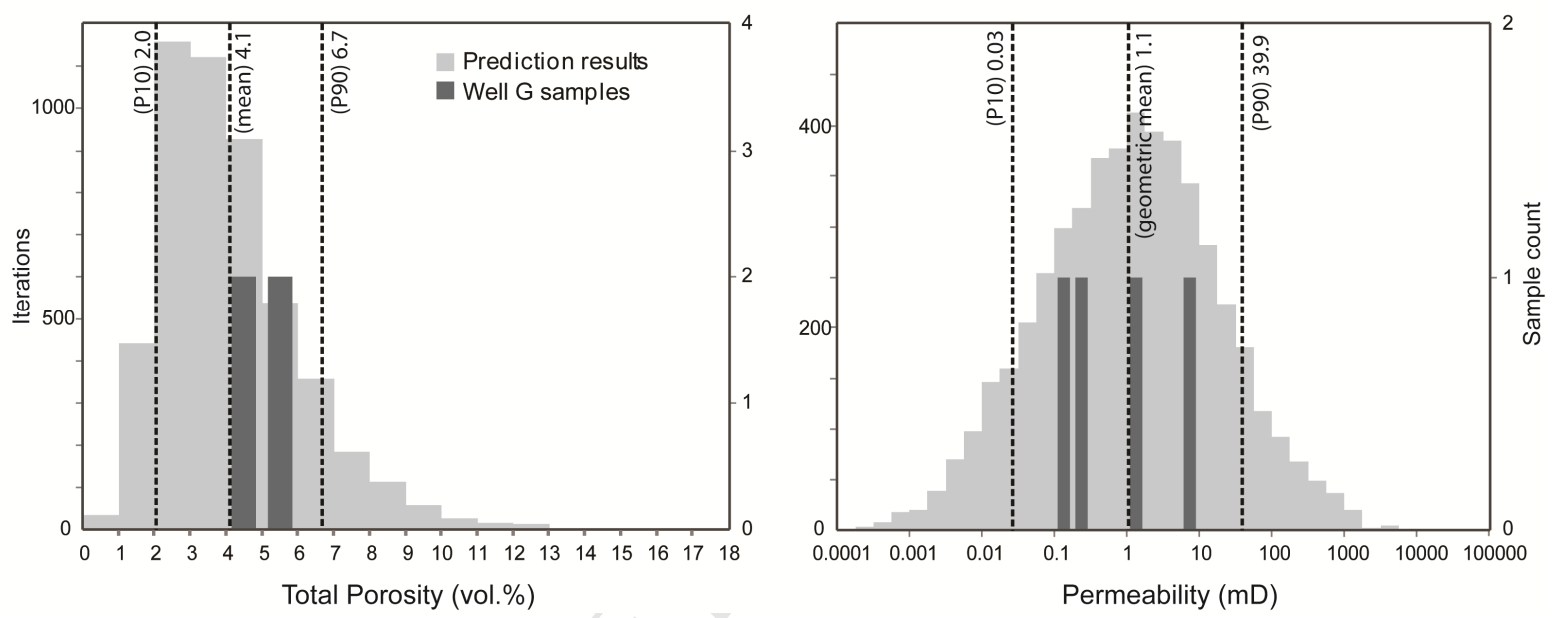

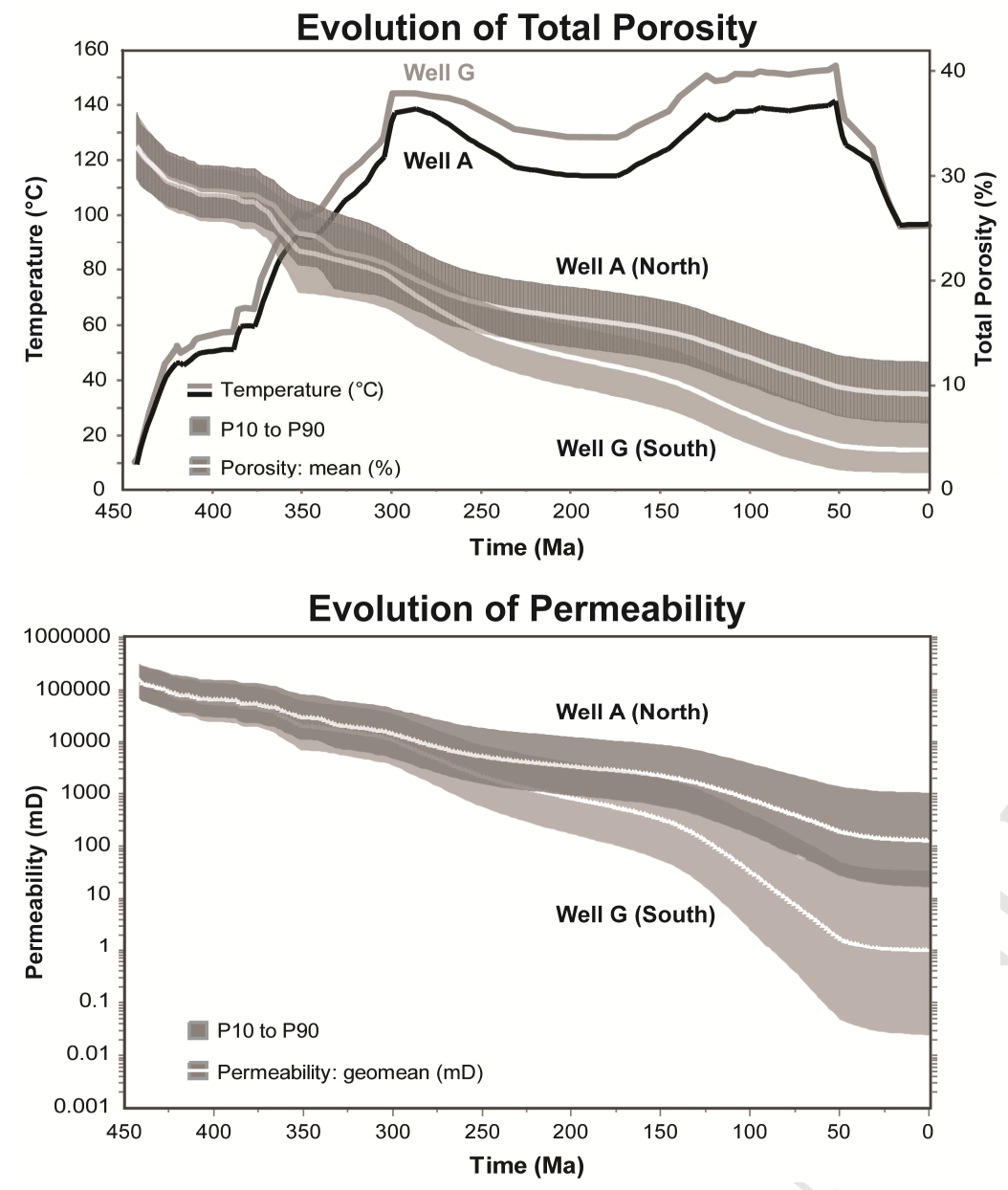
BURIAL DEPTH (m)
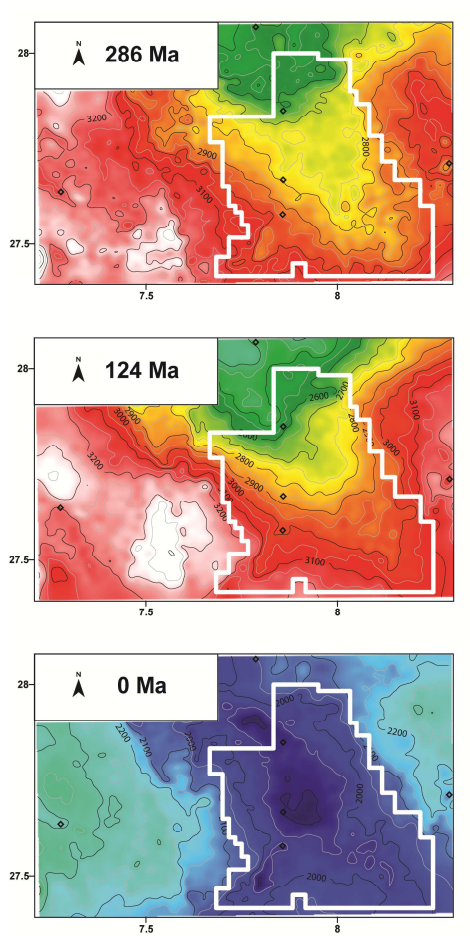

TOTAL POROSITY (Mean; \%)
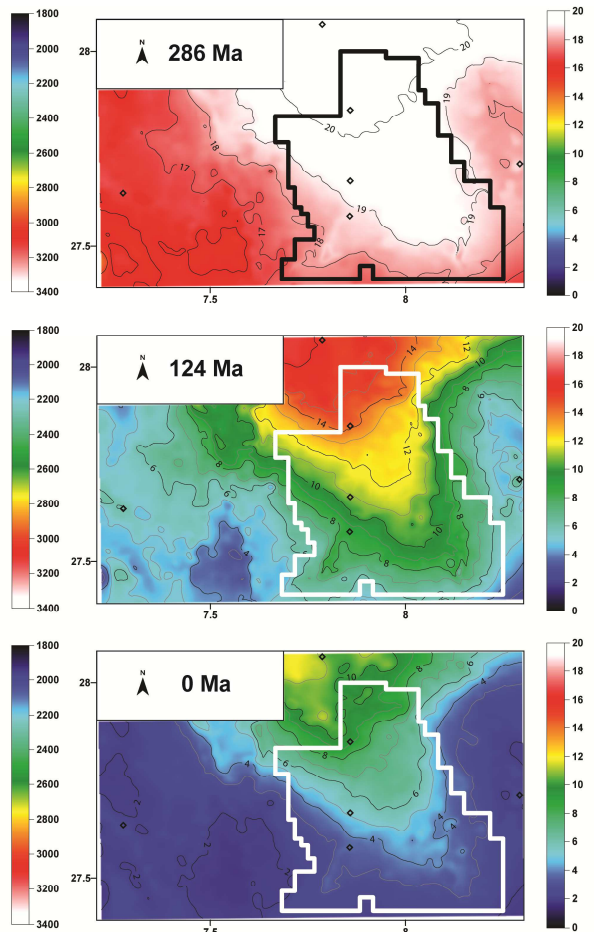

PERMEABILITY (Geomean; mD)
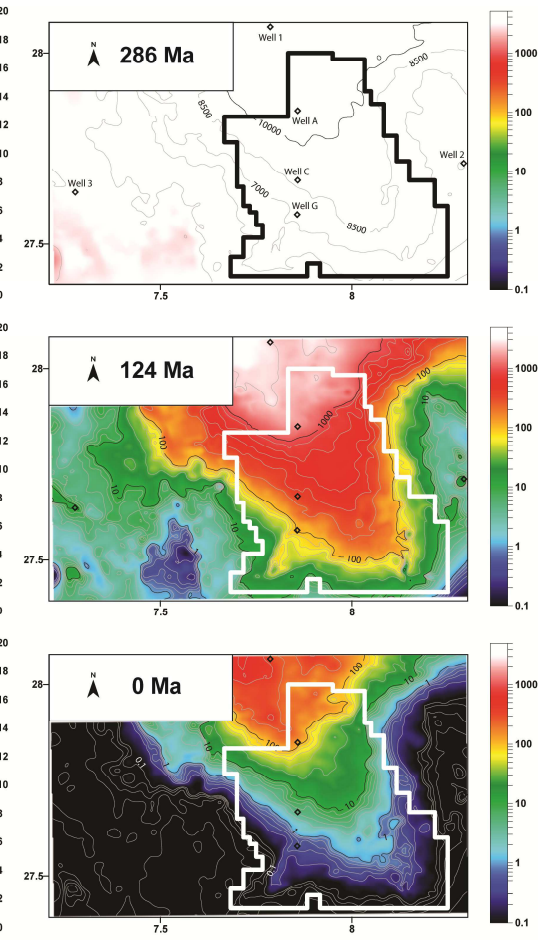
Controls on reservoir quality in exhumed basins - an example from the Ordovician sandstone, Illizi Basin, Algeria

\section{Highlights}

- Integrated study linking petrographic observations with numerical modelling of diagenesis.

- Best reservoir quality found in high-energy, tidally reworked, post-glacial sandstones.

- Quartz cement volume and reservoir quality varies across the field within similar facies.

- Spatial variation in reservoir quality linked to variable thermal history across the field. 